Research Article/Araştırma Makalesi

\title{
Investigation of Research about Massive Open Online Courses (MOOCs): A Thematic Content Analysis Study
}

\author{
Burcu HAYMANA 1 (D) Gökhan DAĞHAN * 2 (iD) \\ ${ }^{1}$ Ministry of National Education, Ankara, Turkey, burcu.haymana@meb.gov.tr \\ ${ }^{2}$ Hacettepe University, Ankara, Turkey, gokhand@hacettepe.edu.tr \\ * Corresponding Author: gokhand@hacettepe.edu.tr
}

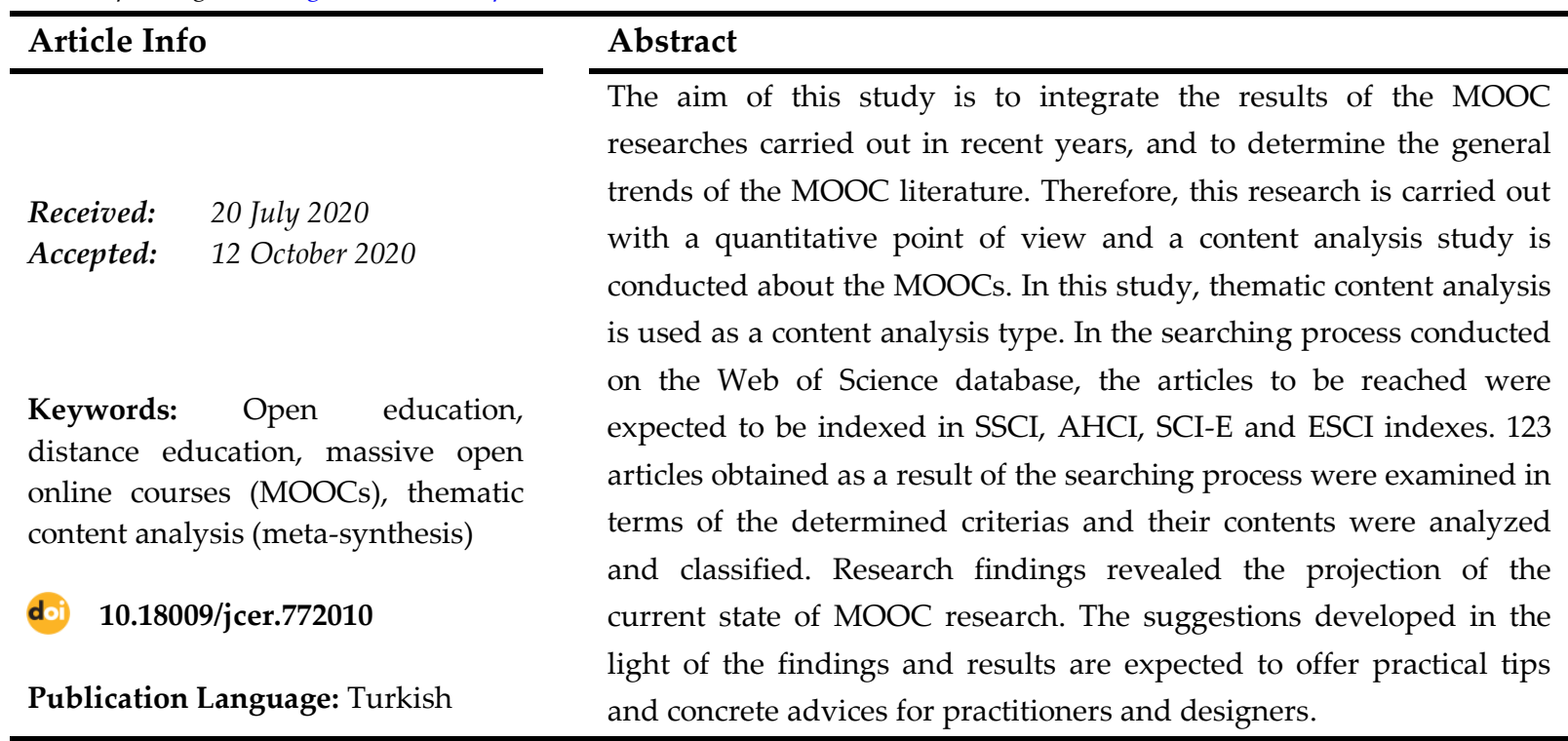

open access CrossMark CC (i)

To cite this article: Haymana, B., \& Dağhan, G. (2020). Kitlesel açık çevrimiçi derslerle ilgili yapılan araştırmaların incelenmesi: Tematik içerik analizi çalışması. Journal of Computer and Education Research, 8(16), 787-820. DOI: 10.18009/jcer.772010

\section{Kitlesel Açık Çevrimiçi Derslerle İlgili Yapılan Araştırmaların İncelenmesi: Tematik İçerik Analizi Çalışması}

\begin{tabular}{|c|c|}
\hline Makale Bilgisi & Öz \\
\hline 20 Теттиz 2020 & $\begin{array}{l}\text { Bu çalışmanın amacı, kitlesel açık çevrimiçi derslerle (KAÇD) ilgili } \\
\text { olarak son yıllarda yapılan araştırmaların sonuçlarını toparlayıcı bir }\end{array}$ \\
\hline 30 Eylül 2020 & $\begin{array}{l}\text { bakış açısıyla bütünleştirebilmek ve böylece genel eğilimleri } \\
\text { belirleyebilmektir. Dolayısıyla nicel bir bakış açısıyla yürütülmüş } \\
\text { olan bu araştırmada KAÇD’ler hakkında bir içerik analizi çalışması }\end{array}$ \\
\hline $\begin{array}{l}\text { Anahtar kelimeler: Açık eğitim, } \\
\text { uzaktan eğitim, kitlesel açık } \\
\text { çevrimiçi ders (KAÇD), tematik } \\
\text { içerik analizi (meta-sentez) }\end{array}$ & $\begin{array}{l}\text { yapılmıştır. Bu çalışmada, bir içerik analizi türü olarak tematik içerik } \\
\text { analizi kullanılmıştır. Web of Science veritabanı üzerinden yapılan } \\
\text { taramada, ulaşılacak olan makalelerin SSCI, AHCI, SCI-E ve ESCI atıf } \\
\text { indekslerinde taranması beklenmiştir. İnceleme sonucunda elde } \\
\text { edilen } 123 \text { makale, belirlenen ölçütler bakımından ele alınmış ve }\end{array}$ \\
\hline doi) $10.18009 /$ jcer.772010 & $\begin{array}{l}\text { içerikleri analiz edilerek sinıflandırılmıştır. Araştırma bulguları } \\
\text { KAÇD araştırmalarının var olan durumunun projeksiyonunu ortaya }\end{array}$ \\
\hline Yayım Dili: Türkçe & $\begin{array}{l}\text { koymuştur. Elde edilen bulgular ve sonuçlar ışı̆̆ında geliştirilen } \\
\text { önerilerin uygulayıcılara ve tasarımcılara dönük pratik ipuçları ve } \\
\text { somut tavsiyeler sunması beklenmektedir. }\end{array}$ \\
\hline
\end{tabular}




\section{Summary}

\section{Investigation of Research about Massive Open Online Courses (MOOCs): A Thematic Content Analysis Study}

\section{Introduction}

Today, MOOCs, which are emerging and increasing in popularity, have a great importance in delivering pre-planned and prepared educational environments by educators to willing individuals. The concept of MOOC is one of the most concrete examples of the process of integrating information and communication technologies into learning and teaching processes towards learning environments. In these environments, many students interact and learn with the content provided to them. It is revealed in the literature that Massive Open Online Courses (MOOCs) are a current form of online learning (Sayın \& Seferoğlu, 2015). In the literature of MOOC, it is seen that a certain knowledge accumulation is now formed and the design processes of MOOCs, the effect and role of instructional design in this design process, the roles of learner and educator in the course process, interaction and communication patterns on MOOCs are among the subjects that are frequently studied. The purpose of this research is to reveal the results of recent researches on MOOCs with a collective perspective and to identify general trends. When this goal is reached, the current situation regarding the current situation and orientation of the literature on the concept of MOOC can be determined, and inferences can be made about the future of MOOCs.

\section{Method}

This study is a document-based research. Therefore, it is a quantitative study in the form of descriptive research in terms of its findings. In this research, a content analysis study has been conducted on MOOCs. The articles included in the thematic content analysis in the study were expected to be indexed in the Social Sciences Citation Index (SSCI), Arts and Humanities Citation Index (AHCI), Science Citation Index - Expanded (SCI-E) and Emerging Sources Citation Index (ESCI). After certain filtering, there are 123 articles left. As a data collection tool in the research, a publication review chart was created by the researchers. The purpose of creating this chart is to be able to collect the encodings as a whole.

\section{Results}

It has been observed that Sunnie Lee WATSON has the most researches with 7 articles. Sunnie Lee WATSON is followed by William R. WATSON with 5 articles. Later, it 
can be said that 6 authors took part in 3 articles each. Then 35 authors are mentioned in 2 articles and 7 authors in 1 article, respectively. It is seen that the majority of the articles were written by 3 authors (26,016\%). This is followed by articles with 1 author and 2 authors $(19,512 \%)$ and articles with 4 authors (18,699\%). It is seen that there are 10 articles with 5 authors $(8.130 \%)$, there are 6 articles with 6 authors (4.876\%), there are one articles with 7 and 8 authors $(0.813 \%)$, and finally there are 2 articles with 9 authors $(1.626 \%)$. It is seen that the USA takes the first place with 45 articles $(36,585 \%)$. This is followed by China ( $\mathrm{f}=17$; $13,821 \%)$, Canada and England $(f=11 ; 8,943 \%)$, respectively. It is seen that the most articles were made in 2017 ( $f=42 ; 34.146 \%)$. This is followed by $2016(f=38 ; 30.894 \%), 2015(f=29$; $23.577 \%$ ) and $2014(\mathrm{f}=10 ; 8.130 \%)$, respectively. It was observed that the most important factors that served as a data source were university students. It can be said that the sample size in MOOC studies is mostly between 0-250 ( $\mathrm{f}=43 ; 35 \%)$. Within the scope of the research, it was observed that 61 of the MOOC articles clearly stated that a certain research method was used, while 62 of them did not have a clear statement in this sense. Descriptive statistics are the most frequently used data analysis method in studies ( $\mathrm{f}=62 ; 50.1 \%$ ). It is noteworthy that the most frequently discussed issue in the studies belongs to the design processes of MOOCs $(f=25 ; 20.3 \%)$. It is observed that the subject of completing or dropping out MOOCs and participation in MOOCs $(\mathrm{f}=23 ; 18.7 \%)$ and the subject of learner / teacher experiences / opinions in MOOCs $(f=20 ; 16.3 \%)$ follow this, respectively.

\section{Discussion and Conclusion}

When the topics discussed in the studies were brought together and examined in a more holistic manner, it was concluded that 4 categories stand out. Accordingly, it is striking that learner/teacher oriented articles are the most intense category. This is followed by the category of articles focusing on MOOC design, articles on the quality and effectiveness of MOOCs, and most recently, articles highlighting trends in MOOC studies. In the study conducted by Zhu, Sari and Lee (2018), student-focused, design-focused, context and impactoriented (context and impact), other (others) and teacher-focused (instructor focused) respectively. It is seen that there are five groups. In Zhu et al.'s (2018) study, the learneroriented and teacher-oriented categories are divided into two. These two categories again reveal the largest audience cumulatively. In this respect, it can be said that the findings of both studies are consistent. 


\section{Giriş}

Bilgi çağı diye adlandırılan 21. yüzyılda, Dünya önceki yüzyıldan başlayan ve hızla devam eden bir değişimi yaşamakta olup bu değişim süreci, kaçınılmaz bir biçimde öğrenme ve öğrenme süreçlerini de etkilemektedir. Dolayısıyla bireylerin günlük hayatlarını ve diğer yaşantılarını topluma uyumlu bir şekilde geçirebilmeleri için gelişen ve değişen olayları yakından takip etmeleri gerekmektedir. Bu noktada eğitim ve öğretim ortamlarından uzakta olan bireylerin, eğitim olanaklarından faydalanmasını amaçlayan uzaktan eğitim, giderek artan bir yaygınlığa ve popülariteye sahip olmuştur. Uzaktan eğitim, öğrenenin fiziksel olarak öğretenden ayrı olduğu, tek başına veya yüz yüze eğitim dâhil diğer eğitim biçimleriyle birlikte kullanılabilen ve kurumsal olarak da eğitimi veren kurumdan fiziki bir ayrılığın söz konusu olduğu eğitim yöntemidir. İlk dönemlerinde radyo ve televizyon ile verilen eğitimler ilerleyen zamanlarda bilgisayar ve İnternet ile verilmeye başlamış, bu durum uzaktan eğitimde, "Açık Üniversite" denilen bir modelin ortaya çıkmasına da neden olmuştur. Birleşik Krallık'ta 1969 yılında kurulan “Open University - Açık Üniversite”, günümüzde İsrail, Mauritius, Hong Kong ve Sri Lanka gibi, Dünya'nın çok farklı bölgelerindeki çok sayıda ülkede bir eğitim modeli olarak kullanılmaktadır.

Edwards (1995) hızla değişen ve farklılaşan günümüz dünyasında eğitime yeni bir bakış açısı getirmek için "Açık Öğrenme" terimini kullanmaktadır. Açık ve uzaktan öğrenmenin sağladığı zamandan ve mekândan bağımsız olma fırsatı ile sağladığı esneklik, yüz yüze eğitime bir alternatifi beraberinde getirmektedir. Sağladığı bu olanaklar ile gerek Türkiye'de, gerekse de diğer ülkelerde açık öğrenmeye karşı ilgi giderek artmaktadır.

\section{Bağlantıcılık Kuramı}

Teknolojinin gelişmesi, hayatın her alanına girmesi ve yaşamın bir parçası olması öğrenmenin yollarını da değiştirmiştir. Öğrenmenin davranışçı yaklaşımlarda olduğu gibi sadece insan davranışları üzerinden değil, insan davranışları dışında da açıklanabilme ihtiyacı hissedilmiştir. Küreselleşen dünya ile teknolojinin gelişmesi bilginin üzerindeki önemi arttırmıştır. Fakat bilgi geçmiş zamanlarda olduğu gibi sürekli sabit durumda değil, gelişen ve güncellenen bir forma sahip olmuştur. Bu noktada, öğrenmeyi açıklayabilmek için daha güncel kuramlara gereksinim duyulmuştur. Buna bağlı olarak Siemens ve Downes tarafından 2008 yılında ortaya atılan Bağlantıcılık Kuramı, bu eksiklik noktasındaki ihtiyaçları bir parça gidermiştir. Günümüzün gelişen teknolojisinin şartlarına göre Bağlantıcılık Kuramı, öğrenen bireylerin sürekli güncellenen bilgiye erişebilmelerini, 
anlamlandırmalarını ve özümsemelerini öngörmektedir. Bireyin nasıl öğrendiğini açıklamakla birlikte toplulukların da öğrenme durumlarını açıklayabilmektedir. Bağlantıcılık kuramının temelinde günümüzde ortaya çıan ve sürekli olarak büyüyen bilginin öğrenilme şeklinin değişmesi ve bu öğrenme şeklinin mevcut öğrenme kuramları ile açıklanamaması yer almaktadır.

Siemens ve Tittenberger'in (2009) bağlantıcılığı tanımlarken kullandıkları, “bilgi ve biliş, insan ve teknoloji ağları boyunca dağıtılmıştır ve öğrenme bu ağlara bağlanma, ağları büyütme ve ağlarda gezinme sürecidir" biçimindeki ifadeleri, bireyin öğrenmesinin bir ağ oluşturma ve ağlar üzerinde bağlar kurarak bilgiyi anlamlandırma süreciyle açıklanabileceğini ortaya koymaktadır. Günümüz çağında etkileşim ve iletişimin ağlarla örülü olduğu göz önüne alındığında, bağlantıcılığın ağlar ile açıklanan bir öğrenme modeli olarak önerildiği söylenebilir (Siemens, 2005a, 2005b). Siemens'e (2005b) göre bağlantıcılığın temel ilkeleri gereği, sürekli öğrenmeyi kolaylaştırmak için ağlar üzerinde kavramlar arası bağlantıları beslemek ve sürdürmek gerekmektedir ve alanlar, fikirler ve kavramlar arasındaki bağlantıları görebilme yeteneği, temel bir beceridir. Ayrıca bağlantıcılık, yeni anlamlar ve anlayışlar yaratmak için önceki bilgileri mevcut bilgilerle birleştirir (Siemens, 2005b).

Alan yazında bağlantıcılığın kuram olmadığını ileri süren araştırmalar da yer almaktadır. Örneğin bir görüşe göre bağlantıcılık önemli ve geçerli kabul edilmekte, ancak başlı başına bir kuram olmak yerine, öğretim sürecinde kullanılabilecek bir araç olabileceği ileri sürülmektedir. Yine bazı araştırmacılar bir şeye kuram diyebilmek için öğrenmeyi iyi açıklayabilmesi gerektiğini ileri sürmektedirler ve buradan hareketle bağlantıcılığın bir kuram olabileceği görüşünü çürütmeye çalışmaktadırlar. Zira bağlantıcılık öğrenmenin nasıl gerçekleştiğini açıklama, buna farklı bir anlayış getirme ve var olan öğrenme kuramlarının ortaya koyduğu anlayışları doğru bir şekilde betimleme konularında başarısızdır (Kerr, 2006: akt. Demiraslan-Çevik, 2015). Bununla birlikte her öğrenme kuramının güçlü ve zayıf yönleri bulunmaktadır. Başka bir ifadeyle, her bir kuram öğrenmeye ilişkin bazı boyutları daha iyi açıklayabilirken bazı boyutları ise göreli olarak ihmal edebilmektedir. Sayısal çağın öğrenme kuramı olarak sunulan Bağlantıcılık Kuramında da durum farklı değildir. Ayrıca Siemens (2005b) de bilinen öğrenme kuramlarının çoğunun öğrenme sürecine odaklandığını, neyin öğrenildiğinin değeri ile ilgilenmediklerini belirtmektedir. Bağlantıcılığın cevap vermeye çalıştı̆̆ı, neden yeni bir öğrenme kuramına ihtiyaç duyulduğu sorusuna Dunaway (2011) ise, 
yeni teknolojiler, yeni öğrenme ve yeni okuryazarlıklar perspektifinden yantt vermektedir. Nasıl değerlendirilirse değerlendirilsin bağlantıcılık, sunduğu farklı bakış açısıyla günümüzde dikkate alınmaya değer bir kuram olarak öne çıkmaktadır.

Bağlantıcılık kuramının da belirttiği gibi, öğrenme yaşamın her anına ve yerine dağılmıştır. Bu durum yaşam boyu öğrenme kavramının önemini attırmıştır. Yaşam boyu öğrenmeye duyulan ihtiyaca yönelik olarak çevrimiçi ortamlarda eğitimciler ve profesyoneller tarafından belli disiplinler çerçevesinde eğitimlerin oluşmasının yolu açılmıştır. Büyük ölçüde küreselleşmenin neden olduğu eğitimin yaşam boyu algılanması, Kitlesel Açık Çevrimiçi Dersler'in (KAÇD) ortaya çıkmasına temel oluşturmuştur. KAÇD’ler eğitim ve öğretimin bilindik sınıf ortamından çıkıp, zamandan ve mekândan bağımsız, esnek olanakların sağlandığı ortamlar olarak hizmet vermesini sağlamıştır. Dolayısıyla günümüzde bireyler eğitim ve öğretime daha ucuz ve kolay yollar aracilı̆̆yla ulaşmaktadırlar. Verilen eğitimin yüz yüze eğitimden daha geniş kitlelere hitap etmesi popülerliğinin artmasının nedenlerinden biri olmuştur. Dünyanın herhangi bir yerindeki bir insan ile dünyanın bir diğer tarafındaki insan haberleşebilir, aynı eğitimi alabilir ve etkileşimli özellikleri sayesinde iletişimde bulunabilirler. Bireylerin daha farklı kültürler ile etkileşim içinde olması, daha farklı öğrenme çıktıları sağlamakta, yaratıcılığı ve çeşitliliği de arttırmaktadır.

Çevrimiçi Öğrenme ve Kitlesel Açık Çevrimiçi Dersler (KAÇD)

Günümüzde ortaya çıkan ve popülerliği giderek artan KAÇD’ler eğitimciler tarafından önceden planlanmış ve hazırlanmış eğitim ortamlarının istekli bireylere ulaştırılması konusunda büyük öneme sahiptirler. Bu bakımdan KAÇD’ler için “Çevrimiçi öğrenmenin geniş kitleler için ortaya konmuş ve genişletilmiş bir formudur." da denebilir. Watson, Loizzo, Watson, Mueller, Lim ve Ertmer (2016), KAÇD’lerin çevrimiçi öğrenme ile açık eğitsel kaynakların birleşimi olduğunu ifade etmişlerdir. KAÇD kavramı, bilgi ve iletişim teknolojilerin öğrenme öğretme süreçlerine bütünleştirilmesi sürecinin öğrenme ortamlarına dönük en somut örneklerinden biridir. Bu ortamlarda çok sayıda öğrenci kendilerine sağlanan içeriklerle etkileşim kurar ve öğrenir.

Kitlesel Açık Çevrimiçi Derslerin (KAÇD - Massive Open Online Courses (MOOCs)) çevrimiçi öğrenmenin güncel bir şekli olduğu alan yazındaki araştırmalarda ortaya konmaktadır (Sayın \& Seferoğlu, 2015). KAÇD terimi George Siemens ve Stephen Downes tarafından 2008 yılında açılan "Connectivism and Connective Knowledge (CCK08)" dersi 
kapsamında dünya çapında 2200 katılımcının yararlandığ 1 bir çevrimiçi açık ders ortamını tanımlamalarıyla alan yazına girmiştir (Sayın \& Seferoğlu, 2015). Bu ders kampüs içinde 23 öğrenci tarafından kredili ders olarak alınmış, aynı zamanda dünyanın farklı yerlerinden çok sayıda çevrimiçi katılımcı tarafından da izlenmiştir. Daha sonra 2012 yılında Stanford Üniversitesinde Sebastian Thrun ve Peter Norvig adlı iki öğretim üyesinin açık ve ücretsiz olarak önerdikleri "Yapay Zekâya Giriş" adlı dersleri diğer bir KAÇD denemesi olarak dikkati çekmiştir (Lin \& Zhang, 2014). 190 ülkeden 160.000'den fazla öğrencinin katıldığ bu ders, gerçek anlamda ve ilk kez kitlesel bir ders olarak kabul görmüştür. Bu ilk KAÇD hareketi, günümüzde Udacity olarak adlandırılan KAÇD platformunun temellerini oluşturmuştur. Ortaya çıktığı günden bu yana KAÇD olgusunun istikrarlı bir şekilde büyüdüğü ve geliştiği söylenebilir.

KAÇD'lerin küçük ölçekli çevrimiçi öğrenme ortamlarından farkını ortaya koyan temel iki kavram bulunmaktadır. Bunlardan ilki açıklık, diğeri ise kitleselliktir. Açıklık, derslerin her yaştan öğrenen tarafından ulaşılabilir olduğu anlamına gelmektedir. Açık olmak katılımcıların sisteme istedikleri zaman girmesi ve çıkması, katılımcıların birbirleriyle etkileşim içinde olmaları ve dersin açık bir içeriğe sahip olması demektir (Rodriguez, 2012). Farklı bir bakış açısında göre açıklığın iki temel çıkış noktası vardır. Bunlardan ilki, KAÇD’nin onu düzenleyen kurum dişındaki öğrencilere de açık olması ve bir önkoşul gerektirmemesi (açık bir kaydının olması) iken, diğeri de açık eğitim kaynakları (open education resources - OER) kavramından gelmesidir (Sanchez-Gordon \& Luján-Mora, 2014). Burada açıklıktan kastedilenin açık erişim ve açık içerik olduğu söylenebilir. Naidu (2019) ise açıklığı, açık erişim yayımcılı̆̆ından ve açık eğitim kaynaklarından çok daha fazlası olarak nitelendirmekte, açık eğitimin aynı zamanda eğitim fırsatlarına açık erişimi ile öğrenme ve öğretmede açık öğrenme stratejilerinin benimsenmesini de içermesi gerektiğini ifade etmektedir.

KAÇD'lerin kitlesel olması ise çok fazla öğrenciye hitap etmesi ile ilgilidir. Bu platformların dünyanın her yerindeki öğrenenler için kullanıma sunulmuş olması bu kavramın oluşmasına neden olmuştur. Küçük ölçekli çevrimiçi öğrenme ortamlarına göre KAÇD’lerin farkı, çok sayıda öğrenciye hizmet sunulabilmesidir. Pilli ve Admiraal (2016) açıklık ve kitlesellik kavramlarını kullanarak KAÇD’leri sınıflama amaçlı 2x2'lik bir matrisle 4 gruba ayırmışlardır. Bu sınıflamada açıklık ve kitlesellik durumlarına göre KAÇD’lerin 4 ayrı çeyrekle incelendiği dikkati çekmektedir. İlk çeyrek küçük ölçekli ve daha az açı olan 
KAÇD’ler ile ilgilidir. Bu tür KAÇD’lerde katılımcıların sayısı sınırlıdır (binler yerine 200-500 katılımcı). Bu çeyrekte ders içeriklerinin açıklığı da, dersin bazı kısımlarına erişim için bir ücret gerekebileceğinden sınırlıdır. $\mathrm{Bu}$ tür KAÇD’ler genellikle kampüs tabanlı yükseköğretimde kullanılan KAÇD’lere örnek olabilir. Küçük ölçekli ve daha açık olan ikinci çeyrekteki KAÇD’lerde, ders materyalleri ve / veya sinavlar tüm katılımcılara ücretsiz olduğu için, içeriğin açık olduğu söylenebilir. Büyük ölçekli ve daha az açık olan KAÇD’ler, kısıtlı içeriğe ücretsiz olarak sınırsız katılım sağlayan üçüncü çeyrekte yer almaktadır. Bu grupta geleneksel uzaktan yükseköğretim derslerinin yer aldığı söylenebilir. Son grup olan 4. çeyrekte ise sınırsız katılım ve sınırsız içerik vardır. Bu gruptaki KAÇD’ler, kurumsal uzmanların bilgi ve fikirlerini videolar ve kurs içerikleri aracılığıyla ifade ettikleri, en iyi bilinen KAÇD türleridir (Pilli \& Admiraal, 2016).

KAÇD’ler 2008 yılından bu yana eğitim alan yazınında kendisine yer bulmuştur. Son 12 yılda KAÇD alan yazını zenginleşmiş, bunun bir sonucu olarak gerek ulusal, gerekse uluslararası platformlarda gün geçtikçe daha çok KAÇD uygulamasına rastlanır olmuştur. Günümüzde insanların öğrenme öğretme süreçlerine zaman ve mekândan bağımsız olarak katılmak istemeleri, bilgi çağının da getirdiği bir sonuç olarak, KAÇD uygulamalarının popülerliğinin giderek artmasını sağlamıştır. Böylece alan yazında giderek daha çok sayıda araştırmaya rastlanır olmuştur. Bu araştırmalarının ortaya koyduğu bulguların ve sonuçların bütüncül bir şekilde incelenip, raporlaştırılmasının alan yazına birkaç boyutuyla katkı sağlayabileceği ileri sürülebilir. Bunlardan ilki araştırmalarda bugüne kadar var olan eğilimleri belirleyebilmek ve bir diğeri de eğilimlerden hareketle gelecek araştırmalara 1şık tutabilmektir.

\section{Araştırmanın Amacı ve Önemi}

KAÇD alan yazınında artık belli bir blgi birikiminin oluştuğu ve KAÇD’lerin tasarım süreçlerinin, bu tasarım sürecinde öğretim tasarımının etkisinin ve rolünün, ders süreçlerinde öğrenen ve eğitimci rollerinin, KAÇD’ler üzerindeki etkileşim ve iletişim örüntülerinin sıklıkla çalışılan konular arasında olduğu görülmektedir. Ancak Mackness, Waite, Roberts ve Lovegrove (2013) ile Sayın ve Seferoğlu'nun (2015) da belirttiği gibi, KAÇD’lerin pedagojik yönünün biraz daha araştırılması gerektiği söylenebilir. Son 12 yıldır pedagojik bakış açılarına, KAÇD’ler üzerinde öğrenmenin nasıl gerçekleştiğine ve öğretimsel katkılara ilişkin sınırlı sayıda çalışmanın olduğu dikkati çekmektedir. Ayrıca KAÇD’ler ile ilgili alan yazındaki araştırma eğilimlerinde var olan durumun ortaya konmasına dönük 
çeşitli dönemlerde yapılan tarama türündeki araştırmaların da, ya çok sınırlı zaman aralıklarını ele aldığı, ya da çok farklı veritabanları üzerinde gerçekleştirildiği söylenebilir. $\mathrm{Bu}$ bağlamda bu araştırmanın amacı, KAÇD'lerle ilgili olarak son yıllarda yapılan araştırmaların sonuçlarını toparlayıcı bir bakış açısıyla ortaya koymak ve genel eğilimleri belirleyebilmektir. Bu amaca ulaşıldığında, KAÇD kavramıyla ilgili alan yazının var olan durumuna ve yönelimine ilişkin mevcut durum tespit edilebilecek, ayrıca KAÇD'lerin geleceğine yönelik de çıkarımlarda bulunulabilecektir. KAÇD’ler gelecekte büyük kitlelere hizmet verebilecek bir öğrenme platformu olma potansiyeline sahiptir. Bu bağlamda gelecekte daha çok kullanılabilecekleri öngörülebilir. Elde edilen bulgular ışığında geliştirilecek öneriler sayesinde uygulayıcılara ve tasarımcılara dönük pratik ipuçları ve somut tavsiyelerde bulunulması beklenmektedir.

\section{Araştırma Problemi}

KAÇD uygulamalarında var olan araştırma eğilimleri nelerdir?

\section{Alt Problemler}

1. KAÇD’lerle ilgili yayımlanan çalışmalarda hangi yazarın kaç makalesi vardır ve yüzdeleri kaçtır?

2. KAÇD’lerle ilgili yayımlanan çalışmalar, genellikle kaç yazarlı olarak gerçekleştirilmiştir ve yüzdeleri nedir?

KAÇD'lerle ilgili yayımlanan çalışmaların;

3. Yazarlarının ülkelere göre dağılımları nasıldır?

4. Gerçekleştirildikleri üniversitelere göre dağılımları nasıldır?

5. Yıllara göre dağılımları nasıldır?

6. Yayımlandıkları dergilere göre dağılımları nasıldır?

7. Atıf istatistiklerinin dağılımları nasıldır?

8. Veri kaynaklığı türlerinin dağılımları nasıldır?

9. Araştırma gruplarının genişliğine ilişkin dağılımları nasıldır?

KAÇD'lerle ilgili yayımlanan çalışmalarda

10. Temel alınan kuram ve modellerin dağılımı nasıldır?

11. Kullanılan örnekleme yöntemlerinin dağılımı nasıldır?

12. Kullanılan araştırma yöntemlerinin dağılımı nasıldır?

13. Kullanılan veri analizi yöntemlerinin dağılımı nasıldır?

14. Kullanılan veri toplama araçlarının dağılımı nasıldır?

15. Kullanılan anahtar kelimelerin dağılımı nasıldır? 
16. Ele alınan konuların dağılımı nasıldır?

\section{Yöntem}

$\mathrm{Bu}$ çalışma doküman incelemesi temelli bir araştırma niteliği taşımaktadır. Dolayısıyla ortaya konan bulguları bakımından betimsel araştırma türünde nicel bir çalışmadır. Bu araştırmada KAÇD'ler hakkında bir içerik analizi çalışması yapılmıştır. İçerik analizinin özünde, büyük miktardaki verinin ortak noktalarının belirlenerek daha bütüncül sentezlere ulaşılması yer almaktadır. Bu bakımdan içerik analizinde veri indirgemesinin yapıldığı söylenebilir (Schreirer, 2012). Bu çalışmada, bir içerik analizi türü olarak metasentez (tematik içerik analizi) yöntemi kullanılmıştır. Meta-sentez (tematik içerik analizi) çalışmalarıyla aynı konu üzerine yapılan araştırmaların tema veya ana şablonlar aracılığıyla eleştirel bir bakış açısıyla sentezlenmesi ve yorumlanması mümkün olmaktadır (Çalık \& Sözbilir, 2014). Ayrıca tematik içerik analizi çalışmaları belli bir alanda yapılmış nitel araştırmaların yine nitel bir anlayışla ele alınıp, benzerlik ve farklılıkların karşılaştırmalı olarak ortaya konmasını içermektedir (Çalık \& Sözbilir, 2014). Çalışmada meta-sentezin (tematik içerik analizinin) seçilmesinin sebebi, belirli ölçütlerle ulaşılabilen konu alanı çalışmalarındaki benzerlik ve farklılıkların belirlenerek, söz konusu çalışmalarda var olan durumun benzer veya farklı boyutlarıyla birlikte derinlemesine irdelenmeye çalışılmasıdır. Diğer bir neden ise konunun güncelliği sebebiyle betimsel içerik analizi yapılabilecek kadar çok sayıda yayının henüz bulunmamasıdır. KAÇD'ler henüz son 12 yıldır çalışılan bir konu alanıdır. Ayrıca meta-analiz yapılabilecek sayıda deneysel araştırmanın henüz gerçekleştirilmediği söylenebilir.

\section{Veri Toplama Süreci}

Araştırmada tematik içerik analizine alınan makalelerin seçimi ve belirlenmesi süreci 12.03.2018 tarihinde gerçekleştirilmiştir. Web of Science veritabanı üzerinden yapılan taramada, ulaşılacak olan makalelerin Social Sciences Citation Index (SSCI), Arts and Humanities Citation Index (AHCI), Science Citation Index-Expanded (SCI-E) ve Emerging Sources Citation Index (ESCI) atıf indekslerinde taranması beklenmiştir. Tarama yapılırken, başlığında "MOOC" sözcüğünün kısaltılmış veya açık hali geçen, yayın türü makale olan, yayın kategorisi "Education \& Educational Research" veya "Education, Scientific Disciplines" olan tam metin erişimli özgün araştırma makaleleri herhangi bir yıl kısıtlaması olmaksızın araştırılmıştır. Herhangi bir yıl sınırlaması verilmemesinin sebebi, KAÇD konu alanında yapılan araştırmaların henüz yeni olması ve bu nedenle de güncelliğini yitirmiş 
araştırmalara rastlanmamasıdır. İlk tarama sonucunda 178 makaleye ulaşılmıştır. Daha sonra yayınların analiz edilmesinin sağlıklı bir şekilde gerçekleştirilebilmesi için, dilinin İngilizce olması ölçütüne göre yeniden filtreleme yapılmış, bu aşamada İspanyolca 40, Fransızca 13 ve Portekizce 2 makale kapsam dışına çıkarılmıştır. Sonuç olarak incelemesi gerçekleştirilecek olan İngilizce 123 makale kalmıştır. Web of Science'da eğitsel bağlamda 3. ve son bir kategori daha yer almaktadır. "Education, Special" olarak adlandırılan bu kategoride KAÇD alan yazınından özgün hiçbir araştırma makalesi yayımlanmamıştır. Dolayısıyla bu çalışma “Education \& Educational Research" ve "Education, Scientific Disciplines" kategorileriyle sınırlıdır. İlgili tematik içerik analizine kaynaklık edecek makalelere erişebilmek için Web of Science veritabanında yapılan taramaya ilişkin arama ifadeleri aşağıdaki gibidir:

TITLE: (MOOC)

Refined by: DOCUMENT TYPES: (ARTICLE) AND

WEB OF SCIENCE CATEGORIES: (EDUCATION EDUCATIONAL RESEARCH OR EDUCATION SCIENTIFIC DISCIPLINES) AND

LANGUAGES: (ENGLISH) AND

WEB OF SCIENCE INDEX: (WOS.SSCI OR WOS.SCI OR WOS.AHCI OR WOS.ESCI)

Timespan: All years.

$\mathrm{Bu}$ inceleme sonucunda elde edilen 123 makale, başlıkları, özetleri ve yayımlandıkları dergiler doğrultusunda Web of Science ara yüzünde incelenmiş ve hiçbir makalenin kapsam dışında tutulmamasına karar verilmiştir. Bu ilk incelemede, 123 makalenin eğitsel bağlamda gerçekleştirildiği ve bu nedenle alanla ilgili oldukları kanaatine varılmıştır. Ardından 123 makalenin tam metinleri indirilmeye başlanmıştır. Bu süreçte Web of Science ara yüzünde makaleye ilişkin verilen sıra numaraları, makalelerin tam metinlerine dosya ismi olarak verilmiş ve 1-123 şeklinde numaralandırılarak sistematik bir şekilde arşivlenmiştir.

Veri Toplama Araçları ve Verilerin Analizi

Araştırmada veri toplama aracı olarak araştırmacılar tarafından bir yayın inceleme çizelgesi oluşturulmuştur. Bu çizelgenin oluşturulma amacı kodlamaları bütüncül olarak toparlayabilmektir. Bu yayın inceleme çizelgesinde, incelenen makalelerin sıra numarasına, yayımlandıkları derginin adına, yayının yılına, yazar sayısına, atıf sayısına, araştırma grubunun niteliğine, araştırma grubunun genişliğine / sayısına yer verilmiştir. Ayrıca eğer makalede ifade edildiyse kuramsal temellere, varsa örnekleme yöntemine, araştırma 
yöntemine, veri analizi yöntemine, veri toplama aracına, anahtar kelimelere, çalışılan konuya, bağımlı ve bağımsız değişkenlere göre de kodlamalar yapılmıştır.

Yayın inceleme çizelgesine son şekli verildikten sonra, araştırmacının makaleleri inceleyip, içeriklerini analiz etmesi sürecine geçilmiştir. Bu süreçte 123 makalenin belirlenen başlıklara göre kodlanması 2 ayda tamamlanmıştır. İlk aşamada fark edilemeyen kodlamalara süreç içerisinde farklı zamanlarda tekrar dönülüp göz atılmış ve kodlama çizelgesine kodlamalar sonrasında son şekli verilmiştir. Verilerin analizi sonrasında, bulguların sunumu aşamasında yüzde ve frekans istatistiklerinden yararlanılmıştır.

\section{Araştırmanın Geçerlik ve Güvenirliği}

Araştırmacı kodlamaları tamamladıktan sonra, kodlamalar üzerinde uzlaşıya varma aşamasına geçilmiştir. Bu noktada, 123 makalenin 12 tanesi (yaklaşık \%10’u) Microsoft Excel programında $=$ RASTGELEARADA $(1 ; 23)$ şeklinde bir fonksiyon kullanılarak seçilmiştir. Bu rastgele seçilen 12 makalenin kodlamaları kontrol edilmiştir. Kodlamalarda dikkati çeken küçük hatalar giderilmiştir. Daha sonra, yine aynı fonksiyonla seçilen ve ilk seçimden farklı olan 25 makale, araştırmacının kodlamalarından bağımsız olarak yeniden kodlanmıştır. Bu noktada, bağımsız araştırmacılar arasındaki kodlama tutarlılığının ve uzlaşı yüzdesinin hesaplanması amaçlanmaktadır. Yapılan kodlamalar neticesinde Cohen'in Kappa katsayısı 0,69 olarak hesaplanmıştır. Bu değer, kodlayıcılar arasındaki uyumun iyi düzeyde olduğunu göstermektedir. Bir çeşit uzman kanısı da sayılabilecek bu sürecin sonunda araştırmanın güvenirliğine katkıda bulunulmuş ve kodlama tablosuna son şekli verilmiştir.

\section{Bulgular}

Bu kısımda, araştırmanın bulgularına alt problemler sırasıyla yer verilmiştir.

KAÇD'lerle İlgili Yayımlanan Çalışmalarda Yazar İstatistiklerine İlişkin Bulgular

Araştırma problemlerinden ilki, KAÇD'lerle ilgili makalelerde hangi yazarın kaç makalesi olduğunun belirlenmesidir. Tablo 1 incelediğinde, araştırma kapsamında ele alınan makalelerdeki yazarların adları, kaçar makaleye sahip oldukları ve yüzdeleri sunulmuştur.

Tablo 1. KAÇD makalelerinin yazarlarına ait betimsel istatistikler

\begin{tabular}{lcc}
\multicolumn{1}{c}{ Yazar(lar)ın Adı Soyadı } & $\begin{array}{c}\text { Makale Sayısı } \\
\text { (f) }\end{array}$ & Yüzdesi (\%) \\
\hline Sunnie Lee Watson & 7 & $\% 5,691$ \\
\hline William R. Watson & 5 & $\% 4,065$ \\
\hline $\begin{array}{l}\text { Cengiz Hakan Aydın, Rebecca Yvonne Bayeck, Kathryn W. Jablokow, Jenny } \\
\text { Mackness, David E. Pritchard, George Veletsianos }\end{array}$ & 3 & $\% 2,439^{*}$ \\
\hline $\begin{array}{l}\text { Syed Hani Abidi, Carlos Alario-Hoyos, Syed Ali, Jon Baggaley, Frances Bell, } \\
\text { Mohamed Amine Chatti, Kimberly F. Colvin, Colin Fredericks, Mariana Funes, } \\
\text { Adelina Hristova, Darco Jansen, Marco Kalz, Woori Kim, Jeremy Knox, Allison }\end{array}$ & 2 & $\% 1,626^{*}$ \\
\hline
\end{tabular}


Littlejohn, Alwina Liu, Min Liu, Jamie Loizzo, Cormac Mcgrath, Emily Mckelroy,

Colin Milligan, Chad Mueller, Pedro J. Munoz-Merino, Aamna Pasha, Mar Pérez-

Sanagustín, Saif Rayyan, Jennifer Richardson, Ulrik Schroeder, Robert Schuwer,

Peter Shepherdson, Antonio Teixeira, Marold Wosnitza, Ahmed Mohamed

Fahmy Yousef, Jingjing Zhang, L. Zhang

Nor Aniza Abdullah, Francesco Agrusti, Terence C. Ahern, Mary D. Ainley,

Maija Aksela, Hamdan Alamri, Giora Alexandron

1

$\% 0,813^{*}$

*: Her bir yazar için geçerli yüzde

Tablo 1 incelendiğinde, Sunnie Lee WATSON'ın 7 makale ile en çok sayıda araştırmaya sahip olan yazar olduğu görülmüştür $(\% 5,691)$. Sunnie Lee WATSON'1, 5 makale ile William R. WATSON izlemektedir $(\% 4,065)$. Daha sonra 6 yazarın ise 3'er makalede yer aldığı söylenebilir. Ardından sırasıyla 35 yazarın 2 makalede, 7 yazarın ise 1 makalede adı geçmektedir.

$\mathrm{Bu}$ çalışma kapsamında tematik içerik analizine alınan makalelerin kaçar yazarlı olduğu incelendiğinde, makalelerin 1 ile 9 arasında yazar sayısına sahip olduğu görülmektedir. Tablo 2'de makalelerin kaçar yazarlı oldukları, frekansları ve yüzdeleri sunulmuştur.

Tablo 2. Makalelerin yazar sayılarına ilişkin betimsel istatistikler

\begin{tabular}{lcc}
\hline Yazar Sayısı & Makale Sayısı (f) & Yüzdesi (\%) \\
\hline 9 Yazarlı & 2 & 1,626 \\
8 Yazarlı & 1 & 0,813 \\
7 Yazarlı & 1 & 0,813 \\
6 Yazarlı & 6 & 4,876 \\
5 Yazarlı & 10 & 8,130 \\
4 Yazarlı & 23 & 18,699 \\
3 Yazarlı & 32 & 26,016 \\
Yazarlı & 24 & 19,512 \\
Yazarlı & 24 & 19,512 \\
\hline TOPLAM & 123 & 100 \\
\hline
\end{tabular}

Tablo 2 incelendiğinde, makalelerin büyük çoğunluğunun 3 yazarlı olarak gerçekleştirildiği görülmektedir $(\% 26,016)$. Bunu sırasıyla 1 yazarlı ve 2 yazarlı makaleler $(\% 19,512)$ ile 4 yazarlı makaleler $(\% 18,699)$ izlemektedir. 5 yazarlı makalelerin 10 tane olduğu $(\% 8,130), 6$ yazarlı makalelerin 6 tane olduğu $(\% 4,876)$, 7 ve 8 yazarlı makalelerin birer tane olduğu $(\% 0,813)$ ve son olarak 9 yazarlı makalelerin ise 2 tane olduğu görülmektedir $(\% 1,626)$.

KAÇD'lerle İlgili Yayımlanan Çalışmaların Yazarlarının Ülkelerine Göre Dağılımlara İlişkin Bulgular

Araştırmanın bir diğer bulgusu ise, makalelerde yer alan yazarların hangi ülke uyruğuna sahip olduklarına ilişkindir. Tablo 3'de yazarların ülkelerine göre sahip oldukları makale sayılarına ve yüzdelerine yer verilmiştir. 
Tablo 3. Yazarların ülkelerine göre makale istatistikleri

\begin{tabular}{lcc}
\hline Ülke & Makale Sayısı (f) & Yüzdesi (\%) \\
\hline ABD & 45 & 36.585 \\
Çin & 17 & 13.821 \\
Kanada; İngiltere & 11 & 8.943 \\
İspanya & 9 & 7.317 \\
Avustralya & 7 & 5.691 \\
İskoçya & 6 & 4.878 \\
Türkiye & 5 & 4.065 \\
Almanya; İtalya; Hollanda & 4 & 3.252 \\
İsveç; İsviçre; Tayvan & 3 & 2.439 \\
Şili; Danimarka; Misır; Kazakistan; Malezya; Meksika; & 2 & 1.626 \\
Pakistan; Portekiz & & 0.813 \\
Ekvador; Finlandiya; İran; İrlanda; Kuveyt; Fas; Yeni & 1 & \\
Zelanda; Polonya; Rusya; Güney Afrika Cumhuriyeti & &
\end{tabular}

Tablo 3 incelendiğinde, A.B.D.'nin 45 makale ile ilk sırada yer aldığg görülmektedir $(\% 36,585)$. Bunu sirasiyla Çin $(\mathrm{f}=17 ; \% 13,821)$ ile Kanada ve İngiltere $(\mathrm{f}=11 ; \% 8,943)$ izlemektedir. Türkiye ise bu sıralamada 5 makale ile $(\% 4,065) 8$. sirada yer almaktadır.

KAÇD’lerle İlgili Yayımlanan Çalışmaların Gerçekleştirildikleri Üniversitelere Göre Dağılımlara İlişkin Bulgular

Araştırma kapsamında incelenen makaleler bütüncül olarak ele alındığında, araştırmaların yürütüldüğü üniversiteler, makale sayıları ve yüzdeleri Tablo $4^{\prime}$ de sunulmuştur.

Tablo 4. Araştırmaların yürütüldükleri üniversitelere ait betimsel istatistikler

\begin{tabular}{lcc}
\hline Üniversitenin Ad1 & Makale Sayısı (f) & Yüzdesi (\%) \\
\hline Purdue Univ. & 7 & 5.691 \\
\hline Penn State Univ. & 6 & 4.878 \\
\hline Anadolu Univ., Athabasca Univ., MIT, Open Univ. & 4 & 3.252 \\
\hline Univ. Carlos III Madrid, Univ. Edinburgh & 3 & 2.439 \\
\hline Aga Khan Univ., Beijing Normal Univ., EADTU, Fontys Univ. Appl. Sci., & \\
Glasgow Caledonian Univ., Harvard Univ., Indiana Univ., Karolinska & \\
Inst., Nazarbayev Univ., Open Univ. Netherlands, Peking Univ., & \\
Pontificia Univ. Catolica Chile, Rhein Westfal Th Aachen, Royal Rd Univ., & 2 \\
Simon Fraser Univ., Stockholm Univ., Suny Albany, Swinburne Univ. & \\
Technol., Univ. Aberta, Univ. Cantabria, Univ. Nebraska Lincoln, Univ. & \\
Texas Austin, Univ. Zurich & \\
\hline Aarhus Univ., Adelphi Univ., Anhui Polytech Univ., Anqing Normal & \\
Univ., Atatürk Univ., Australian Catholic Univ., Beuth Univ. Appl. Sci. & \\
Berlin, Brigham Young Univ., Brunel Univ. London, Cent. Michigan & \\
Univ., Changzhou Univ., Charite Univ. Med Berlin, Charles Sturt Univ., \\
Chinese Acad. Governance, Cornell Univ., Curtin Univ., Dublin City \\
Univ., Duke Network Anal Ctr., Duke Univ.
\end{tabular}

Tablo 4 incelendiğinde Purdue Üniversitesinde 7 makalenin $(\% 5,691)$, Penn State Üniversitesinde 6 makalenin $(\% 4,878)$, Anadolu Üniversitesi, Athabasca Üniversitesi, MIT ve Açık Üniversite'de 4'er makalenin $(\% 3,252)$ ve Carlos III Madrid Üniversitesi ile Edinburg 
Üniversitesi'nde 3'er makalenin (\%2,439) yapıldığı görülmektedir. Daha sonra sirasıyla 23 farklı üniversitede 2'şer çalışmanın ve 19 farklı üniversitede ise 1'er çalışmanın yapıldığ söylenebilir.

KAÇD'lerle İlgili Yayımlanan Çalışmaların Yıllara Göre Dă̆ılımlarına İlişkin Bulgular

Araştırma kapsamında tematik içerik analizine tabi tutulan makalelerin yayımlandıkları yıllara ilişkin betimsel istatistikler Şekil 1'de sunulmuştur.

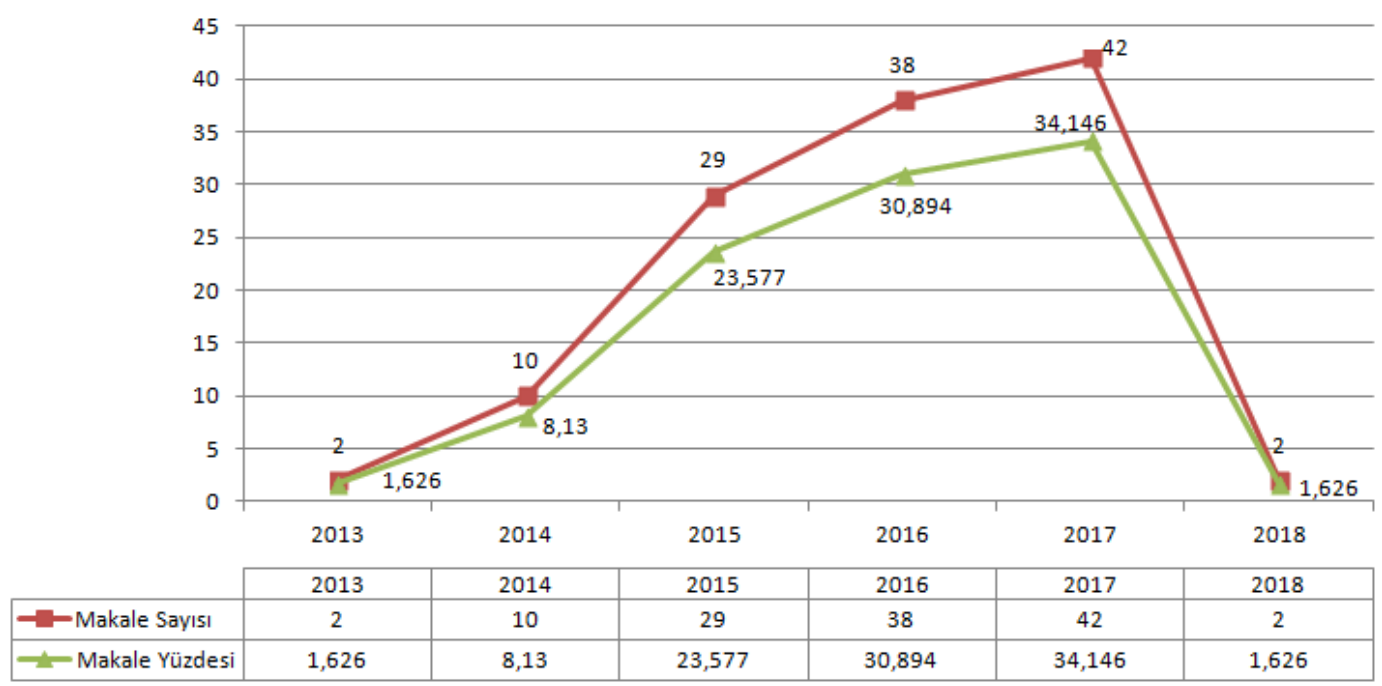

Şekil 1. Yıllara göre yayımlanan makale sayılarını ve yüzdelerini gösteren grafik

Şekil 1 incelendiğinde, en çok makalenin 2017 yılında yapıldı̆̆ı $(\mathfrak{f}=42 ; \% 34,146)$ görülmektedir. Bunu sirasıyla 2016 yılı (f=38; \%30,894), 2015 yılı (f=29; \%23,577) ve 2014 yılı (f=10; \%8,130) izlemektedir. 2013 yılında yalnızca 2 çalışma olduğu göze çarpmaktadır. 2018 yılında da sadece 2 çalışma analize dâhil edilmiştir ancak bu sayının düşük olmasının sebebi, tematik içerik analizine alınacak çalışmaların taramasının 2018 yılı başında yapılmasıdır.

KAÇD'lerle İlgili Yayımlanan Çalışmaların Yayımlandıkları Dergilere Göre Dağılımlarına İlişkin Bulgular

Araştırma kapsamında incelenen makalelerin hangi dergilerde yayımlandıkları araştırılmış, elde edilen bulgular Tablo 5' de sunulmuştur. Tablo 5. Makalelerin yayımlandığı dergilere ait betimsel istatistikler

\begin{tabular}{|ccc} 
Dergi Adı & $\begin{array}{c}\text { Makale Sayısı } \\
\text { (f) }\end{array}$ & Yüzdesi (\%) \\
\hline Research in Open and Distributed Learning & 13 & 10.569 \\
C\&E) & 9 & 7.317 \\
esearch in Open and Distance Learning & 9 & 7.317 \\
& 7 & 5.691 \\
merging Technologies in Learning & 7 & 5.691 \\
nal Technology (BJET) & 6 & 4.878 \\
& 6 & 4.878
\end{tabular}


Journal of Computer Assisted Learning

Journal of Computing in Higher Education

Eurasia Journal of Mathematics Science and Technology Education

(EURASIA)

Education Sciences

Open Learning
4.065

4.065

3.252

2.439

2.439

Tablo 5 incelendiğinde, 13 makalenin International Review of Research in Open and Distributed Learning (IRRODL) dergisinde, 9 makalenin ise International Review of Research in Open and Distance Learning (IRRODL) dergisinde yayımlandı̆̆ dikkati çekmektedir. International Review of Research in Open and Distributed Learning (IRRODL) dergisinin önceki adı International Review of Research in Open and Distance Learning (IRRODL) olduğu için, toplamda 22 makalenin $(\% 17,886)$ aynı dergide yayımlandığı söylenebilir. Bu bulgu söz konusu derginin yayın politikası olan, Dünya çapında açık ve dağıtılmış öğrenmede özgün araştırma, kuram ve uygulamaları ele alması ile örtüşmektedir. Dolayısıyla en çok araştırmanın bu dergide yayımlanmış olması şaşırtıcı bir saptama değildir. Daha sonra sirasiyla Computers E Education dergisinde 9 (\%7,317), Distance Education ve International Journal of Emerging Technologies in Learning dergilerinde ise 7 'şer $(\% 5,691)$ makale yayımlanmıştır. Ardından British Journal of Educational Technology (BJET) ve Open Praxis dergilerinde 6'şar makale (\%4,878), Journal of Computer Assisted Learning ile Journal of Computing in Higher Education dergilerinde 5'er makale $(\% 4,065)$, Eurasia Journal of Mathematics Science and Technology Education (EURASIA) dergisinde 4 makale $(\% 3,252)$ ve son olarak Education Sciences ve Open Learning dergilerinde 3'er makale yayımlanmıştır. Daha sonra 10 dergide 2 makale ve 26 dergide ise 1 makale yayınlandığ1 görülmüştür. Bu dergiler büyük bir çeşitlilik gösterdiği için Tablo 5'de sunulmamıştır.

KAÇD'lerle İlgili Yayımlanan Çalışmaların Atıf İstatistiklerinin Dağılımlarına İlişkin Bulgular

Araştırma kapsamında tematik içerik analizine alınan makalelerin atıf istatistikleri incelenmiş ve toplam atıfı 11 ve üzerinde olan makalelere ilişkin bulgular Şekil 2'de sunulmuştur. 10 ve altında atıf alan ve hiç atıf almayan makalelerin istatistikleri kayda değer görülmediği için Şekil 2' de sunulmamıştır ancak betimleme amaçlı yorumlanmışlardır. 


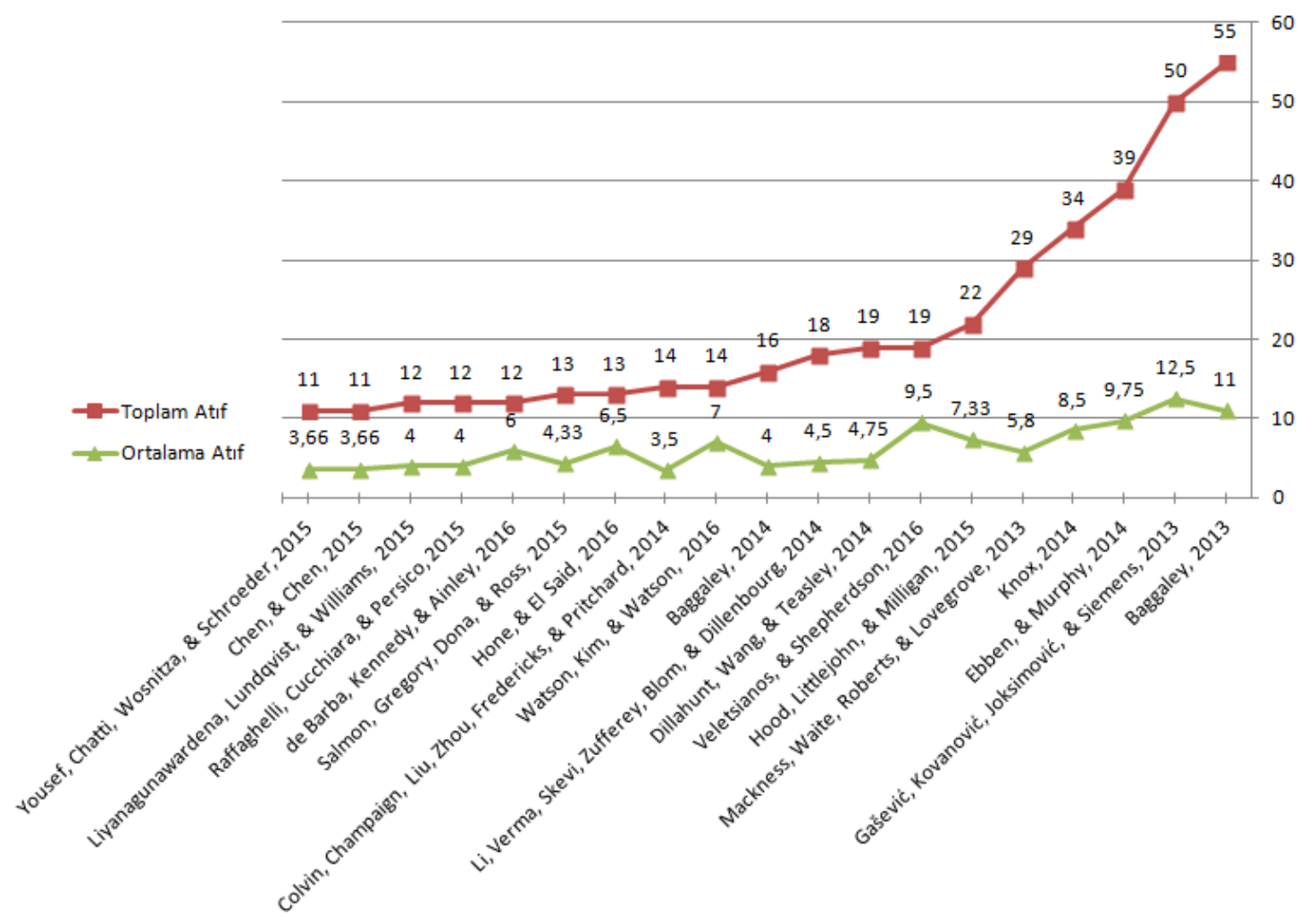

Şekil 2. Toplam atıfı 11 ve üzerinde olan makalelerin, ortalama ve toplam atıf sayılarını gösteren grafik

Araştırma kapsamında tematik içerik analizine alınan 123 makalenin 19 tanesinin atıf istatistikleri Şekil 2'de görülmektedir. Bu şekilde sunulan bulguların dışında, 49 makalenin henüz hiç atıf almadığı bulgusuna ulaşılmıştır. Ayrıca 15 makalenin 1, 12 makalenin 2, 13 makalenin 3 ve 3 makalenin ise 4 atıfı olduğu görülmüştür. Ayrıca 5 atıfı olan 4, 6 atıfı olan 5 ve 7,8 ve 9 atıfı olan birer makalenin olduğu dikkati çekmektedir.

Araştırmada elde edilen bulgulara göre, yıllık ortalama atıf sayısındaki yoğunluğun "Where is Research on Massive Open Online Courses Headed? A Data Analysis of the MOOC Research Initiative" başl1klı ve International Review of Research in Open and Distance Learning dergisinde yayımlanan makalede olduğu dikkati çekmektedir. Bu makale Dragan Gašević, Vitomir Kovanović, Srecko Joksimović ve George Siemens tarafından kaleme alınmıştır. Bu makalenin yıllık ortalama 12,5 atıfı, toplamda ise 50 atıfı bulunmaktadır. $\mathrm{Bu}$ makaleyi, Distance Education dergisinde 2013 yılında yayımlanan "MOOC Rampant" isimli makalenin takip ettiği görülmektedir. Bu makalenin toplamda 55, yıllık ise ortalama 11 atıfı vardır. "MOOC Rampant" makalesini ise, 2014 yılında Learning Media and Technology dergisinde yayımlanan "Unpacking MOOC scholarly discourse: A review of nascent MOOC scholarship" isimli makale izlemektedir. Bu makalenin de toplam 39, yıllık ortalama 9,75 atıf1 bulunmaktadır. 
KAÇD'lerle İlgili Yayımlanan Çalışmaların Veri Kaynaklı̆̆ı Türlerinin Dağılımlarına İlişkin Bulgular

Tablo 6'da araştırma kapsamında tematik içerik analizine alınan makalelerin veri kaynaklığı türleri görülmektedir.

Tablo 6. KAÇD araştırmalarına veri kaynaklığı eden kitleler, frekansları ve yüzdeleri

\begin{tabular}{lcc}
\hline \multicolumn{1}{c}{ Araştırmalara veri kaynaklı̆̆ı eden kitleler } & Makale Frekansı (f) & Yüzdesi (\%) \\
\hline Üniversite öğrencileri & 25 & 20 \\
Makale-tez-elektronik kaynaklar & 8 & 6,5 \\
Lise öğrencileri & 5 & 4 \\
İş hayatı çalışanları & 4 & 3,3 \\
Diğer & 52 & 42 \\
Belirsiz & 29 & 23,6 \\
\hline TOPLAM & 123 & 100 \\
\hline
\end{tabular}

Elde edilen bulgulara göre araştırmaya veri kaynaklığı eden unsurların başında en fazla üniversite öğrencilerinin yer aldığı dikkati çekmektedir ( $f=25 ; \% 20)$. Üniversite öğrencilerinden sonra, araştırmaya veri kaynaklığı eden unsurlar incelendiğinde, 2. sıranın elektronik kaynaklara ait olduğu görülmektedir ( $f=8 ; \% 6,5)$. Elektronik kaynakları sırasıyla lise öğrencileri $(\mathrm{f}=5 ; \% 4)$ ve iş hayatı çalışanları izlemektedir $(\mathrm{f}=4 ; \% 3,3)$. Diğer araştırmaların ise, KAÇD eğitmenleriyle, hem eğitmenler hem de öğrencilerle, örgün eğitim dışındaki yaşam boyu öğrenenlerle, yaş grubu ve örgün eğitim alıp almadığı belirtilmeyen öğrencilerle veya KAÇD araştırmalarının analiz edilmesiyle gerçekleştirildiği söylenebilir. Bu tür araştırmaların frekansları birer tanedir ve toplamda 52 araştırmanın dağınık olarak farklı veri kaynakları üzerinde yürütüldüğü söylenebilir. Ayrıca 29 araştırmada ise belirli bir hedef kitlenin net olarak ifade edilmediği dikkati çekmektedir.

KAÇD'lerle İlgili Yayımlanan Çalışmaların Araştırma Gruplarının Genişlik Dă̆ılımlarına İlişkin Bulgular

Tablo 7'de araştırma kapsamında tematik içerik analizine alınan makalelerde araştırma gruplarının genişlikleri ve betimsel istatistikleri sunulmaktadır.

Tablo 7. KAÇD araştırmalarında araştırma gruplarının genişlikleri, frekansları ve yüzdeleri

\begin{tabular}{lcc}
\hline Araştırma grubunun genişliği & Makale Frekansı (f) & Yüzdesi (\%) \\
\hline $0-249$ & 43 & 35 \\
$250-499$ & 12 & 10 \\
$500-749$ & 8 & 6,5 \\
$750-999$ & 7 & 6 \\
$1000-1999$ & 6 & 5 \\
2000 ve üzeri & 11 & 9 \\
Belirsiz & 36 & 28,5 \\
\hline TOPLAM & 123 & 100 \\
\hline
\end{tabular}


Araştırmada ulaşılan bulgulara göre, KAÇD çalışmalarında örneklem genişliğinin büyük çoğunlukla 0-250 arasında olduğu görülmüştür (f=43; \%35). 0-250 öğrenen arasında katılımcıyla yürütülen KAÇD araştırmalarını sırasıyla 250-500 ( $\mathrm{f}=12 ; \% 10)$ ve 500-750 ( $\mathrm{f}=8$; $\% 6,5)$ katılımcıyla yürütülen araştırmalar izlemektedir. 750-1000 arasında (f=7; \%6) ve 10002000 arasında (f=6; \%5) toplam 13 araştırma yer almaktadır. 2000 üzeri örneklem genişliğiyle yürütülen 11 araştırma bulunmaktadır (\%9).

KAÇD'lerle İlgili Yayımlanan Çalışmalarda Temel Alınan Kuram ve Modellerin Dă̆ılımına İlişkin Bulgular

Araştırma bulgularına göre tematik içerik analizine alınan makalelerin çoğunluğunda belli bir kuramsal temelin ifade edilmediği görülmüştür. Belli bir kuramı temel alan makalelerin ise yoğunluklu olarak iki farklı kuramsal temele dayandırıldığı görülmektedir. Bunlardan ilki Bağlantıcılık Kuramı, diğeri ise KAÇD’lerle ilgili mevcut alan yazındır. Bunların dışında da alan yazına kaynaklık eden başka kuram veya modellerin olduğu söylenebilir. Etkinlik Kuramı (Activity Theory), Teknoloji Kabul Modeli (Technology Acceptance Model), Planlı Davranış Kuramı (Theory of Planned Behavior) ve eleştirel postmodernizm yaklaşımı bunlara örnek olarak verilebilir.

KAÇD'lerle İlgili Yayımlanan Çalışmalarda Kullanılan Örnekleme Yöntemlerinin Dağılımına İlişkin Bulgular

Elde edilen bulgulara göre, çok az sayıda makalede bir örnekleme yönteminin kullanması tercih edilmiştir. Bu örnekleme yöntemleri arasında en çok kullanılanın basit rastgele örnekleme yöntemi olduğu (f=3), bu yöntemi tabakalı örnekleme (f=2) ve amaçlı örnekleme ( $\mathrm{f}=2$ ) yöntemlerinin izlediği söylenebilir. 116 çalışmada ise herhangi bir evrenden örneklem seçimi yoluna gidilmemiş, dolayısıyla mevcut gruplar üzerinde genelleme kaygısı güdülmeden, taramaya dönük araştırmalar yürütülmüşstür.

KAÇD'lerle İlgili Yayımlanan Çalışmalarda Kullanılan Araştırma Yöntemlerinin Dă̆ılımına İlişkin Bulgular

Araştırma kapsamında tematik içerik analizine alınan KAÇD makalelerin 61'inde belli bir araştırma yönteminin kullanıldığının açıkça ifade edildiği, 62 tanesinde ise bu anlamda net bir ifadenin yer almadığı görülmüştür. Söz konusu 61 araştırmada kullanılan araştırma yöntemleri ve betimsel istatistikleri Tablo 8' de sunulmuştur. 
Tablo 8. Araştırma yöntemi net olarak ifade edilen araştırmalara ait betimsel istatistikler

\begin{tabular}{lcc}
\hline Araştırma yöntemi & Kullanım sayıları (frekans) & Toplam \\
\hline Nitel araştırma yöntemi & 19 & 12 \\
Karma araştırma yöntemi & 4 \\
Nicel araştırma yöntemi & 4 \\
Örnek olay araştırma yöntemi & 4 \\
Derleme çalışması & 3 \\
Betimsel çalı̧̧ma & 3 \\
Durum çalışması & 2 \\
Tasarım tabanlı araştırma yöntemi & 2 \\
İlişkisel (korelasyonel) araştırma yöntemi & 2 \\
İçerik analizi & 1 \\
Eylem araştırması & 1 \\
Fenomenolojik araştırma yöntemi & 1 \\
Nedensel karşılaştırmalı araştırma yöntemi & 1 \\
Netnografik araştırma yöntemi & 1 \\
Bibliyometrik yaklaşım & 1 \\
Tarama çalışması & 61 \\
\hline
\end{tabular}

Tablo 8 incelendiğinde, 19 araştırmada nitel araştırma yönteminin, 4 araştırmada ise nicel araştırma yönteminin kullanıldığı görülmektedir. Bu çalışmalarda, nitel ya da nicel yöntemlerin hangi türlerinden yararlanıldığı net olarak ifade edilmemiştir. Ancak Tablo 8'deki tüm yöntemler bütüncül olarak ele alındığında, araştırma yöntemlerinin çeşitlilik gösterdiği görülmektedir. Araştırmalarda deneysel yöntemin kullanılmamış olması önemli bir saptama olarak ön plana çıkmaktadır. Ayrıca 12 araştırmada ise, karma araştırma yöntemlerinin tercih edildiği de göze çarpmaktadır.

KAÇD’lerle İlgili Yayımlanan Çalısmalarda Kullanılan Veri Analizi Yöntemlerinin Dă̆ılımına İlişkin Bulgular

Tablo 9'da araştırma kapsamında tematik içerik analizine alınan makalelerin veri analiz yöntemleri ve frekansları sunulmaktadır.

Tablo 9. Tematik içerik analizine alınan makalelerin veri analiz yöntemleri ve frekansları

\begin{tabular}{lc}
\hline Veri analiz yöntemi & Kullanım sayıları (frekans) \\
\hline Betimsel istatistik (yüzde, frekans, minimum, maksimum, & 62 \\
ortalama, standart sapma, varyans) & 10 \\
İçerik analizi & 8 \\
Lojistik regresyon & 4 \\
t-testi & 4 \\
Sosyal ağ analizi & 3 \\
Ki kare testi & 2 \\
Etkileşim analizi & 2 \\
Faktör analizi & 1 \\
Katılımcı - gözlemci analizi & 1 \\
Duygu analizi yöntemi & 1 \\
SWOT analizi & 1 \\
Kruskal Wallis-H testi & 1 \\
Varyans Analizi (ANOVA) & 1 \\
Söylem analizi & 1 \\
Çoklu regresyon & 1 \\
Yol analizi & \\
\hline
\end{tabular}


Araştırmada ulaşılan bulgulara göre, tematik içerik analizine alınan KAÇD çalışmalarında en sık kullanılan veri analizi yönteminin betimsel istatistikler $(\mathrm{f}=62 ; \% 50,1)$ olduğu görülmektedir. Betimsel istatistikleri içerik analizleri ( $\mathrm{f}=10, \% 8)$ takip etmektedir. İçerik analizi yöntemini sırasıyla, lojistik regresyon ( $\mathrm{f}=8, \% 6,5)$, t-testi ve sosyal ağ analizi $(\mathrm{f}=4, \% 3)$ izlemektedir. Veri analiz yöntemi olarak Ki-kare testi üç makalede, etkileşim analizi ve faktör analizi ikişer makalede kullanılmıştır. Geri kalan veri analiz yöntemlerinden, katılımc1-gözlemci analizinin, duygu analizinin, SWOT analizinin, Kruskal Wallis-H testinin, varyans analizinin (ANOVA), söylem analizinin, çoklu regresyonun ve yol analizinin birer makalede kullanıldığı görülmektedir.

KAÇD’lerle İlgili Yayımlanan Çalışmalarda Kullanılan Veri Toplama Araçlarının Dă̆ılımına İlişkin Bulgular

Tablo 10'da araştırma kapsamında tematik içerik analizine alınan makalelerin veri toplama araçları ve frekansları sunulmaktadır.

Tablo 10. KAÇD araştırmalarında makalelerin veri toplama araçları ve frekansları

\begin{tabular}{lc}
\hline Veri Toplama Aracı & Kullanım sayıları \\
\hline Anket & 53 \\
Görüşme & 13 \\
KAÇD bileşenleri & 12 \\
Elektronik veritabanları & 7 \\
Sosyal medya mesajları & 6 \\
Yarı yapılandırılmış görüşme & 6 \\
Sınav & 3 \\
Odak grup görüşmeleri & 3 \\
Rubrik & 3 \\
Gözlem & 2 \\
Log kayıtları & 2 \\
Arama motorları & 1 \\
Times Higher Education tarafından yayımlanan üniversite siralaması & 1 \\
\hline
\end{tabular}

Araştırmada ulaşılan bulgulara göre, tematik içerik analizine alınan KAÇD çalışmalarında en fazla kullanılan veri toplama aracının anket (f=53, \%43) olduğu görülmüştür. Veri toplama yöntemi olarak anketi, görüşmeler ( $\mathrm{f}=13, \% 11)$ ve KAÇD bileşenleri ( $\mathrm{f}=12, \% 10)$ takip etmektedir. Elektronik veri tabanlarının 7 makalede $(\% 5)$ kullanıldığı görülmektedir. Sosyal medya mesajlarının ve yarı yapılandırılmış görüşmelerin 6'şar (\%4) makalede kullanıldığı sonucuna ulaşılmıştır. Veri toplama araçlarından sınavlar, odak grup görüşmeleri, rubrikler, gözlem ve log kayıtlarının da 2'şer makalede $(\% 1,6)$ kullanıldığı tespit edilmiştir. Arama motorlarının ve Times Higher Education tarafından yayımlanan üniversite sıralamasının ise veri toplama aracı olarak birer makalede kullanıldığ 1 saptanmıştır. 
KAÇD'lerle İlgili Yayımlanan Çalışmalarda Kullanılan Anahtar Kelimelerin Dağılımına İlişkin Bulgular

Tablo 11' de araştırma kapsamında tematik içerik analizine alınan makalelerin anahtar kelimeleri ve frekansları sunulmaktadır. 123 makalenin 110 tanesinde bir ya da birden fazla anahtar kelime verildiği görülmüştür.

Tablo 11. KAÇD araştırmalarında makalelerde kullanılan anahtar kelimeler ve frekansları

\begin{tabular}{lc}
\hline Anahtar Kelimeler & Frekans (f) \\
\hline MOOC / Kitlesel açık çevrimiçi kurs / kitlesel açık çevrimiçi ders & 112 \\
Çevrimiçi öğrenme / çevrimiçi kurs / çevrimiçi eğitim & 34 \\
Açı Kurs / Açı eğitim / Açı öğretim / Açı akademik uygulama & 31 \\
Uzaktan eğitim / uzaktan öğrenme & 12 \\
Yaşam boyu öğrenme & 2 \\
\hline
\end{tabular}

Araştırmada ulaşılan bulgulara göre, KAÇD çalışmalarında kullanılan anahtar kelimelerden MOOC / Kitlesel açık çevrimiçi kurs / kitlesel açık çevrimiçi ders anahtar kelimelerinin büyük yoğunlukla ( $\mathrm{f}=112$, \%91) kullanıldı ğ görülmektedir. MOOC / Kitlesel açık çevrimiçi kurs / kitlesel açık çevrimiçi ders anahtar kelimelerini çevrimiçi öğrenme / çevrimiçi kurs / çeorimiçi eğitim anahtar kelimelerinin (f=34, \%28) takip ettiği bulunmuştur. Açık Kurs / Açık eğitim / Açık öğretim / Açık akademik uygulama anahtar kelimelerinin ise 31 makalede geçtiği görülmüştür. Uzaktan eğitim / uzaktan öğrenme anahtar kelimelerinin 12 makalede, yaşam boyu öğrenme anahtar kelimesinin ise 2 makalede kullanıldı̆̆ tespit edilmiştir.

İçerik analizine alınan makalelerin 13'ünde anahtar kelimelere rastlanamamıştır. Bunu sebebi ise, bu makalelerin yayımlandıkları dergilerin ya hiç anahtar kelimelere yer vermiyor oluşu, ya da makalenin yayımlandığı yıl, cilt veya sayı itibariyle anahtar kelime uygulamasının olmamasıdır. Bu 13 makalenin 6's1 British Journal of Educational Technology (BJET) dergisinde, 2 tanesi ise American Journal of Distance Education dergisinde yayımlanmıştır. Bu dergilerde anahtar kelime uygulaması yoktur. Diğer 5 makalenin ise Higher Education Quarterly, International Review of Research in Open and Distance Learning, Online Learning, Educational Leadership ve Educational Theory dergilerinde yayımlandığı görülmüştür.

KAÇD'lerle İlgili Yayımlanan Çalışmalarda Ele Alınan Konuların Dă̆ılımına İlişkin Bulgular

Araştırma kapsamında tematik içerik analizine alınan 123 makalede ele alınan konular incelendiğinde, büyük bir çeşitliliğin olduğu görülmektedir. Konular bağlamında elde edilen bulgular Tablo 12' de verilmiştir. 
Tablo 12. KAÇD araştırmalarının konularına göre dağılımlarına ilişkin betimsel istatistikler

\begin{tabular}{lcc}
\hline Konular & Frekans (f) & Yüzde (\%) \\
\hline KAÇD ortamlarının tasarımı & 25 & 20,3 \\
KAÇD'leri tamamlama veya terk etme, KAÇD'lere katılım & 23 & 18,7 \\
KAÇD'lerde öğrenen / öğretmen deneyimleri / görüşler & 20 & 16,3 \\
KAÇD'ler ve öğrenen özellikleri (motivasyon, doyum, tutum gibi) & 17 & 13,8 \\
KAÇD'lerde etkileşim - iletişim & 14 & 11,4 \\
KAÇD'lerin kalitesi & 12 & 9,8 \\
KAÇD'lerin etkililiği & 10 & 8,1 \\
KAÇD çalışmalarında eğilimler & 2 & 1,7 \\
\hline TOPLAM & 123 & 100 \\
\hline
\end{tabular}

Tablo 12 incelendiğinde, araştırma kapsamında incelenen araştırmalarda en sık ele alınan konunun KAÇD’lerin tasarım süreçlerine ait olduğu dikkati çekmektedir (f=25; \%20,3). Bunu sırasıyla KAÇD'leri tamamlama veya terk etme ile KAÇD'lere katılım konusunun (f=23; \%18,7) ve KAÇD’lerde öğrenen / öğretmen deneyimleri / görüşler konusunun ( $\mathrm{f}=20 ; \% 16,3)$ izlediği görülmektedir. Diğer ele alınan konular ise sirasıyla KAÇD'lerde etkileşim - iletişim ( $\mathrm{f}=14 ; \% 11,4)$, KAÇD'lerin kalitesi ( $\mathrm{f}=12 ; \% 9,8)$, KAÇD'lerin etkililiği ( $\mathrm{f}=10 ; \% 8,1)$ ve KAÇD çalışmalarında eğilimler ( $\mathrm{f}=2 ; \% 1,7)$ olarak belirlenmiştir.

$\mathrm{Bu}$ konular daha bütüncül olarak ele alındığında, öğrenen / öğretmen odaklı makalelerin 74 tane $(\% 60,2)$ olduğu dikkati çekmektedir. KAÇD'leri tamamlama veya terk etme ile KAÇD’lere katılım, KAÇD’lerde öğrenen / öğretmen deneyimleri / görüşler, KAÇD’ler ve öğrenen özellikleri (motivasyon, doyum, tutum gibi) ile KAÇD’lerde etkileşim - iletişim kategorileri birleştirilerek öğrenen / öğretmen odaklı makaleler olarak bir üst başlıkta toplanabilirler. Bu ana kategoriyi 25 makale ile KAÇD tasarımı izlemektedir (\%20,3). Daha sonra KAÇD’lerin kalitesi ve etkililiği bir ana kategoride toplanabilir ve bu kategoride 22 makale yer almaktadır $(\% 17,9)$. Son olarak KAÇD çalışmalarındaki eğilimler ise ayrı bir kategoride değerlendirilebilir $(\mathrm{f}=2 ; \% 1,7)$. Yapılan bu bütüncül sinıflama Şekil 3'de görülmektedir.

Şekil 3'de tematik içerik analizine giren KAÇD araştırmalarının konularına göre gerçekleştirilmiş bütüncül bir sınıflama ortaya konmaktadır. Benzeri bir gruplama Zhu, Sari ve Lee'nin (2018) yapmış olduğu KAÇD araştırmalarındaki eğilimlerle ilgili görgül çalışmasında da yer almaktadır. 


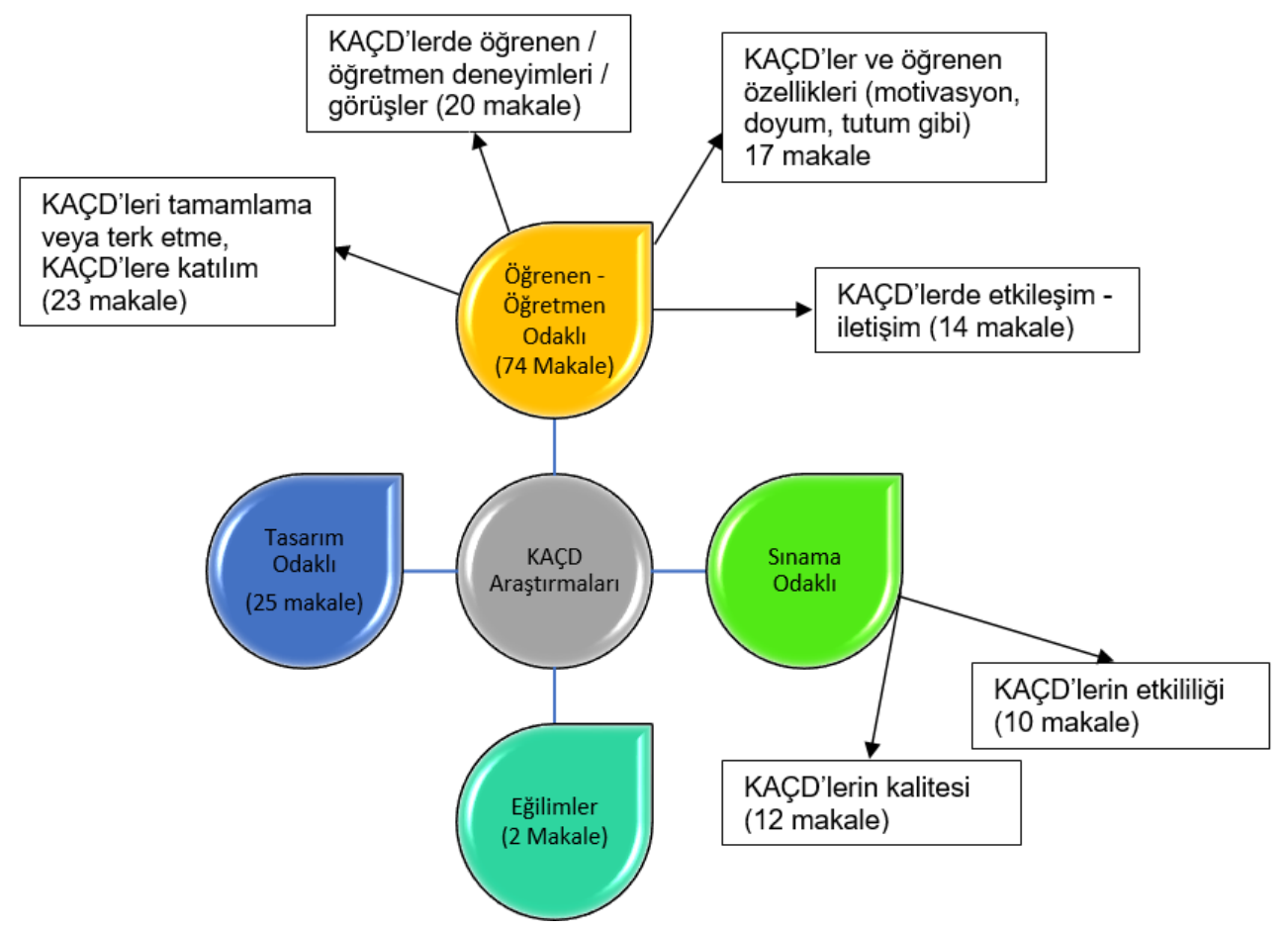

Şekil 3. KAÇD araştırmalarının konularına göre dağılımlarının sınıflandırılması

$\mathrm{Bu}$ çalışmadaki gruplamanın öğretmen-öğretmen odaklı araştırmaları aynı grupta toplaması, Zhu vd.'nin (2018) çalışmasından ayrışan noktasıdır. Bunun dışında, tasarım odaklı, bağlam ve etki odaklı (bu çalışmada sınama odaklı) kategorileri de birbiriyle örtüşmektedir.

\section{Sonuç, Tartışma ve Öneriler}

$\mathrm{Bu}$ araştırmada, KAÇD makalelerinin yazarlarının ülkelerine göre dağılımlarını temel alan ilk incelemede ABD'nin ilk sırada yer aldığı, bunu Çin ve Kanada'nın izlediği görülmüştür. Veletsianos ve Shepherdson'ın (2016) 2013 ve 2015 yılları arasındaki KAÇD çalışmalarını inceledikleri araştırmalarında da ilk sırada ABD'nin yer aldığı, 2. ve 3. sırada ise İngiltere ve Avustralya'nın olduğu sonucuna ulaşılmıştır. Veletsianos ve Shepherdson (2016) araştırmalarında Scopus veritabanı üzerinde bir tarama gerçekleştirmişlerdir ve yaptıkları tarama sonucunda ulaştıkları makalelerin \%50.2'sinin $\mathrm{ABD}^{\prime}$ de yapıldığını görmüşlerdir. Bu araştırmada ise incelenen makalelerin \%37'sinin kökeni ABD'dir. Her iki araştırmada da KAÇD çalışmalarının büyük çoğunluğunun ABD'de yapılmasına ilişkin saptamalar örtüşmektedir. Ayrıca her iki çalışmaya göre de, ilk 6 sırada yer alan ülkeler aynıdır. Bu ülkeler, ABD, Çin, Kanada, Avustralya, İngiltere ve İspanya olup, her iki çalışmada da, bu ülkelere ait makalelerin kümülatif yüzdeleri yaklaşık olarak \%80'dir. Bu saptama aynı zamanda, Zhu vd.'nin (2018) çalışmasında da desteklenmektedir. Bu 
bulgunun, ilk KAÇD uygulamalarının bu ülkelerde denenmesi ve bu ülkelerden hareketle diğer ülkelere yayılmasıyla desteklenebileceği düşünülmektedir. Ayrıca Ebben ve Murpy'nin (2014) çalışmalarında ise en fazla yazarın bulunduğu ülkenin İngiltere olduğu görülmüştür. İngiltere' yi ABD ve Kanada izlemiştir.

KAÇD makalelerinin yayımlandıkları dergiler incelendiğinde, ilk sırayı International Review of Research in Open and Distributed Learning (IRRODL) isimli derginin aldığ dergiyi Computers and Education dergisinin izlediği görülmektedir. Bu bulgu Zhu vd.'nin (2018) araştırmasıyla da tutarlı bir sonucu ortaya koymaktadır. İlk sırayı bu derginin alması şaşırtıcı değildir çünkü bu derginin temel yayın amacı dünya çapında açık ve dağıtılmış öğrenmede özgün araştırma, kuram ve en iyi uygulamaları okurlarıyla paylaşmaktır ve temel hedef kitlesi KAÇD türünden uygulamalardır. Bu araştırmada KAÇD çalışmalarının yayımlandığı diğer dergilerin, BJET ve Distance Education gibi dergiler olduğu görülmüştür. Ancak Zhu vd.'nin (2018) araştırmasında Computers in Human Behavior dergisinin de sıralamaya girdiği dikkati çekmektedir. Bu araştırmada Computers in Human Behavior dergisi sıralamaya girememiştir çünkü bu dergi, Web of Science veritabanında Education $\mathcal{E}$ Educational Research veya Education, Scientific Disciplines kategorilerinde değil, Psychology, Experimental ve Psychology, Multidisciplinary kategorilerinde taranmaktadır. Dolayısıyla, bu çalışmanın hedef kitlesi içerisinde bir dergi değildir. Ayrıca İkinci'nin (2016) TÜBİTAK ULAKBIM, SCOPUS, Bioxbio ve citefactor veritabanları taranarak gerçekleştirdiği tez çalışmasında, ilk sırayı The Chronicle of Higher Education, ikinci sırayı International Review of Research in Open and Distance Learning ve üçüncü sırayı ise Distance Learning dergisinin aldığı görülmüştür. İlk sırada yer alan The Chronicle of Higher Education isimli dergi, Web of Science veritabanında taranmadığı için bu çalışmanın bulgularıyla örtüşmemektedir ancak ikinci ve üçüncü sırada yer alan dergilere ilişkin saptama, bu çalışmanın bulgularıyla benzerlik göstermektedir.

$\mathrm{Bu}$ araştırmada, veri toplama aracı olarak sıklıkla anketlerden ve görüşmelerden yararlanıldığı sonucuna ulaşılmıştır. Bu yöntemleri sırasıyla KAÇD bileşenleri, elektronik veritabanları, sosyal medya mesajları, yarı yapılandırılmış görüşmeler, sınavlar, odak grup görüşmeleri, rubrikler, gözlemler ve log kayıtları izlemektedir. Veletsianos ve Shepherdson'ın (2016) çalışmasında ise araştırmalarda çoğunlukla birden fazla veri toplama aracının kullanıldığı, bunlardan ilk sırayı izleme verilerinin yer aldığı, bu araçları daha sonra sırasıyla anketlerin, görüşmelerin ve diğer veri toplama araçlarının (testler, odak grup 
görüşmeleri, gözlemler vb.) izlediği ortaya konmuştur. Dolayısıyla bu araştırmaların bulguları, izleme verileri dışında örtüşmektedir. Ayrıca Zhu vd.'nin (2018) yaptıkları çalışmanın veri toplama araçları bulguları da en sık kullanılan veri toplama aracının anket olduğu ortaya koymaktadır. Daha sonra sırasıyla veritabanı kayıtları, görüşmeler, tartışma forumları, sınav veya test sonuçları, gözlemler, öğrenme analitikleri ve odak grup görüşmelerinin kullanıldığı görülmüştür. Bu çalışmanın bulguları ile Zhu vd.'nin (2018) çalışmasının bulgularının da örtüştüğü söylenebilir.

$\mathrm{Bu}$ çalışmada, KAÇD araştırmalarında veri analizi yöntemi olarak en sık betimsel istatistiklerin kullanıldığı ortaya konmuştur. Bunu sırasıyla içerik analizleri, lojistik regresyon, t-testi, sosyal ağ analizi ve diğer veri analizi yöntemlerinin izlediği görülmüştür. Veletsianos ve Shepherdson'ın (2016) çalışmasında elde edilen bulgulara göre de en çok kullanılan veri analizi yöntemi betimsel istatistiklerdir. Ardından bunu izleyen veri analizi yöntemi ise korelasyona dayalı ilişkisel yöntemlerdir. Bu durumda betimsel istatistiklerin en sık kullanılan veri analizi yöntemi olduğu söylenebilir ve her iki çalışmanın bulguları da birbirini destekler niteliktedir. Zhu vd.'nin (2018) yaptıkları çalışmanın bulgularına göre de en çok kullanılan veri analiz yönteminin betimsel istatistikler olduğu görülmüştür. Betimsel istatistikleri, çıkarımsal istatistiklerin, içerik analizinin, sosyal ağ analizinin ve tematik analizin izlediği belirlenmiştir. Dolayısıyla yapılan bu çalışmanın bulguları ile Zhu vd.'nin (2018) yaptıkları çalışmanın bulguları birbirini destekler nitelikte görünmektedir. Çalışmalarda sıklıkla betimsel istatistiklerin kullanılmasının sebebinin KAÇD’lerin büyük sayıda öğrenci kitlelerine hizmet etmesi ve büyük kitlelerle deneye dayalı çalışmaların yapılmasının zor olması sebebiyle, genellikle anketlerden yararlanılarak tarama çalışmalarının yapılmış olmasıdır. Bu bakımdan, araştırmacıların tercih edilen bir değişkenle ilgili olarak var olan durumu ortaya koymayı hedeflediği de söylenebilir. Raffaghelli vd.'nin (2015) gerçekleştirdikleri araştırmada da, betimsel istatistiklerin diğer tüm istatistiksel yöntemlere kıyasla başı çektiğini ortaya koymuştur. Bu bulguların tümü, KAÇD’lerle ilgili araştırma alanının hala oldukça yeni olması ve bu nedenle, genel eğilimi anlamak ve araştırmacıların var olan durumu betimlemeye çalışmaları gerçeğiyle uyumludur.

$\mathrm{Bu}$ araştırmada, tematik içerik analizine alınan KAÇD makalelerin sadece yarısında belli bir araştırma yönteminin kullanıldığının açıkça ifade edildiği, diğer yarısında ise bu anlamda net bir ifadenin yer almadığı görülmüştür. Raffaghelli vd. (2015) de, inceledikleri 60 makalenin 9 tanesinde yöntemin belirsiz olduğunu ifade etmişlerdir. Ayrıca bu çalışmada, 
en sık nitel araştırma yönteminin kullanıldığı, bunu sırasıyla karma yöntemler ile nicel araştırma yöntemlerinin, örnek olay araştırma yönteminin ve derleme çalışmalarının izlediği görülmüştür. Bu bakımdan, KAÇD makalelerinde büyük bir yöntemsel çeşitlilik dikkati çekmektedir. Gašević vd. (2014) yaptıkları çalışmalarında, KAÇD makalelerinde kullanılan yöntemsel sıralamanın, karma, nicel ve nitel şeklinde olduğunu ortaya koymuşlardır. Raffaghelli vd.'nin (2015) araştırmasında ise en fazla kullanılan araştırma yöntemi türünün teorik-kavramsal çalışmalar olduğu, bunu sırasıyla karma yöntemli çalışmaların, nicel araştırmaların, nitel araştırmaların ve tasarım tabanlı çalışmaların izlediği görülmüştür. Bozkurt, Akgün-Özbek ve Zawacki-Richter'in 2017 yılında yaptıkları çalışmada ise, KAÇD makalelerinde en sık kullanılan araştırma yönteminin kavramsal / betimleyici / diğer olduğu, bu yöntemi sırasıyla nicel, nitel, veri madenciliği ve analitik çalışmaları ile karma yöntemlerin izlediği görülmektedir. Bozkurt, Özdamar Keskin ve de Waard'ın (2016) çalışmalarında nicel araştırma yöntemleri, nitel araştırma yöntemleri, karma yöntemler, alan yazın incelemesi ve diğer yöntemler şeklinde bir sıralama olduğu dikkati çekmektedir. Zhu vd.'nin (2018) çalışmasında elde edilen bulgu ise, araştırma yöntemlerini kullanım sıklıklarına göre, nicel, karma ve nitel yöntemler şeklinde sınıflandığıdır. Dolayısıyla, araştırma yöntemleri bakımından KAÇD'lerle ilgili yapılan içerik analizi çalışmalarının sonuçları çelişkili bulgular üretmektedir. Hiçbir çalışmanın bulgusunun örtüşmemesi ve birbirini destekler nitelikte olmaması, taramaların farklı zaman aralıklarında, farklı veritabanları üzerinde ve farklı indekslerde gerçekleştirilmiş olmasına bağlanabilir.

Araştırmalarda deneysel yöntemin kullanılmamış olması önemli bir saptama olarak ön plana çıkmaktadır. Bu çalışmada bu bir bulgu olarak ortaya konmuştur. Yine aynı şekilde, alan yazında yapılan farklı çalışmalarla da bu bulgu desteklenmektedir. Bunun sebebinin, kitlesel derslerde deney yapmanın güç olması ve deney koşullarının kontrol edilememesinden kaynaklandığı düşünülmektedir. Ayrıca yukarıda da tartışıldığı üzere, anketlerin en sık kullanılan veri toplama aracı olması ve betimsel istatistiklerin ise en sık kullanılan veri analiz yöntemi olması, çalışmalarda deneysel yönteme eğilimin olmadığının diğer bir göstergesidir. Araştırmacıların KAÇD çalışmalarında küçük örneklemlerle deney yapmak yerine, kitlesel gruplarda tarama çalışmaları yapmayı tercih ettikleri görülmektedir.

$\mathrm{Bu}$ çalışmanın kapsamına giren KAÇD makalelerinin kuramsal temelleri incelendiğinde, makalelerin çoğunda belli bir kuramsal temelin ifade edilmediği görülmektedir. Bu bulgu alan yazındaki diğer saptamalarla da benzer bir sonucu ortaya 
koymaktadır (Bozkurt vd., 2017; Bozkurt vd., 2016). Belli bir kuramsal temele dayandırılan makalelerin ise yoğunluklu olarak Bağlantıcılık Kuramına ve KAÇD’lerle ilgili mevcut alan yazına temellendirildiği söylenebilir. Bunların dışında Etkinlik Kuramı (Activity Theory), Teknoloji Kabul Modeli (Technology Acceptance Model), Planlı Davranış Kuramı (Theory of Planned Behavior) ve eleştirel postmodernizm yaklaşımı da ele alınan kuramsal temeller arasındadır. Bozkurt vd.'nin (2017) araştırması, en sıklıkla kullanılan kuramsal temelin Bağlantıcılık Kuramı olduğunu söylemektedir ve bu saptama, bu araştırma ile benzer bir sonucu ortaya koymaktadır. Ancak diğer kuramlar çok küçük frekanslar düzeyine indiği için, farklılaşmalar mevcuttur. Yani daha az yararlanılan kuramsal temeller arasında bir tutarlılık gözlenememiştir. Bu bulgu, KAÇD’lerin felsefik olarak temelde Bağlantıcılık Kuramına temellendirilmesinden dolayı şaşırtıcı değildir.

$\mathrm{Bu}$ araştırmada, yıllık ortalama en çok atıf alan makalenin, Gašević, Kovanović, Joksimović ve Siemens'e (2014) ait “Where is Research on Massive Open Online Courses Headed? A Data Analysis of the MOOC Research Initiative" başlıklı makale olduğu sonucuna ulaşılmıştır. Bu bulgu, Bağlantıcılık Kuramını ortaya atan kişinin George Siemens olması ve KAÇD çalışmalarının ilk kökenlerinin bu kurama temellendirilmesi bakımından şaşırtıcı değildir. Aynı zamanda, Gašević vd.'nin (2014) çalışmalarında da en çok atıf alan yazarın George Siemens olduğu ortaya konmuştur. Ayrıca Bozkurt vd.'nin (2017) çalışmalarında bir bulgu olarak ortaya konan, en çok atıf alan 5 çalışma ile bu araştırmanın bulgularında ortaya konan ve en çok atıf alan 5 çalışma birbiriyle örtüşmemektedir. Bunun bir sebebinin tarama yıllarının ve tarama yapılan veritabanlarının farklılı̆̆ından kaynaklanabileceği, diğer bir nedeninin ise atıf sayılarının farklı yöntemlerle belirlenmiş olabileceğidir. Bu çalışmadaki ifade edilen atıf sayıları, Web of Science veritabanının ürettiği sayılardır ancak Bozkurt vd.'nin (2017) çalışmasında ise atıf sayılarının hangi yöntemle üretildiği açıkça ifade edilmemiştir. Aynı şekilde, bu çalışmada ulaşılan 123 makaleye Web of Science veritabanından erişilmiştir ancak Bozkurt vd.'nin (2017) çalışmasında ise, incelenen 362 makaleye EBSCO, ERIC, Google Scholar ve Scopus veritabanlarından ulaşılmıştır.

$\mathrm{Bu}$ araştırmada, tematik içerik analizine alınan KAÇD makalelerinin en çok 2017 yilında yapıldığ $1(f=42)$, bunu sirasıyla 2016 yılının (f=38), 2015 yılının (f=29) ve 2014 yılının (f=10) izlediği, 2013 yılında yalnızca 2 çalışmanın olduğu görülmüştür. 2018 yılında ise taramanın yapıldığı zamana bağlı olarak sadece 2 çalışma analize dâhil edilmiştir. 
Liyanagunawardena, Adams ve Williams (2013) tarafından yapılan ve 45 makalenin incelendiği çalışmada, 2008'den 2012'ye doğru hızlı bir artışın olduğu, İkinci'nin (2016) yapmış olduğu tez çalışmasında da, 2009 yılından 2014 yılına doğru sürekli bir artışın olduğu dikkati çekmektedir. Ebben ve Murphy'nin (2014) çalışmasında da, 2009 ve 2013 yılları arasındaki 25 makale incelenmiş, yıllara göre bir artışın olduğuna görülmüştür. Söz konusu doğrusal artışlar, alan yazında belli bir bilgi birikiminin oluşmaya başladığının göstergesidir.

$\mathrm{Bu}$ araştırma kapsamında incelenen araştırmalarda en sık ele alınan konunun KAÇD'lerin tasarım süreçlerine ait olduğu dikkati çekmiş, bu kategoriyi sırasıyla KAÇD’leri tamamlama veya terk etme oranları, KAÇD’lere katılım ve öğrenen / öğretmen deneyimleri / görüşler konusunun izlediği görülmüştür. Diğer ele alınan konular ise sırasıyla KAÇD’lerde etkileşim - iletişim, KAÇD’lerin kalitesi ve etkililiği ile KAÇD çalışmalarında eğilimler olarak belirlenmiştir. Liyanagunawardena vd.'nin (2013) yaptıkları çalışmada, tasarım süreçlerine olmasa da, öğrenen / öğretmen deneyimlerine ilişkin bulgular olduğu görülmektedir. Sa'don, Alias ve Ohshima'nın 2014 yılında yaptıkları çalışmada ise, yükseköğretim kurumlarında kullanılan KAÇD’lerde görülen araştırma eğilimlerine bakılmıştır. En fazla araştırılan konuların sırasıyla, pedagoji, değerlendirme - akreditasyon, bağlılık - motivasyon, bilgi paylaşımı, kültürel çeşitlilik, teknoloji, sosyal etkileşim, KAÇD’lerde katılımcıların kalmaları, öğrenme analitikleri ve politika ile öğretim tasarımı olduğu görülmüştür. Raffaghelli vd.'nin (2015) yaptıkları çalışmanın bulgularına göre KAÇD’lerde öğrenme süreçlerinin en sık ele alınan konu olduğu, bunu sırasıyla, KAÇD’lerde öğrenme için tasarım, KAÇD pedagojisi, kurumsal gelişim için KAÇD'ler ve KAÇD’lerin eğitim teknolojisine katkıları, KAÇD’lerde öğretme süreçleri, KAÇD çalışmalarına yöntemsel yaklaşımlar, alan yazın taramaları ve KAÇD’ler için teknolojik araçlar kategorilerinin izlediği ortaya çıkmıştır. Her ne kadar araştırmalarda kategorizasyon noktasında bir tutarlılık görülmese de, araştırmaların temel konularının büyük oranda ortaklaştı̆̆ söylenebilir. KAÇD’lerin tamamlanma, terk etme oranları, bu ortamlara katılım, bu ortamlardaki öğrenci, öğretmen deneyimleri, etkileşimleri ve görüşleri, söz konusu ortamların kullanımına ilişkin çıkarımlar ile bu ortamların etkililiğe ilişkin bulgular en sık çalışılan konulardır. Araştırmalardaki eğilimlerinin ise en az çalışılan konular arasında olduğu söylenebilir ve bu saptama Raffaghelli vd. (2015) ile Zhu vd.'nin (2018) çalışmalarıyla da desteklenmektedir. Bu 
bulgunun sebebi, konu alanın henüz yeni olmasından ve ancak 12 yıllık bir bilgi birikimini barındırmasından kaynaklanmaktadır.

Araştırmalarda ele alınan konular bir araya getirilerek daha bütüncül olarak incelendiğinde, 4 kategorinin öne çıktığı sonucuna ulaşılmıştır. Buna göre öğrenen / öğretmen odaklı makalelerin en yoğun kategori olduğu dikkati çekmektedir. Bunu KAÇD tasarımı odaklı makaleler, KAÇD’lerin kalitesi ve etkililiği ile ilgili makaleler ve son olarak KAÇD çalışmalarındaki eğilimleri ortaya koyan makalelerin yer aldığı kategori izlemektedir. Zhu vd.'nin (2018) yaptıkları çalışmada öğrenci odaklı (student-focused), tasarım odaklı (design-focused), bağlam ve etki odaklı (context and impact), diğer (others) ve öğretmen odaklı (instructor focused) olmak üzere sırasıyla beş grubun bulunduğu görülmektedir. Zhu vd.'nin (2018) çalışmasındaki öğrenen odaklı ve öğretmen odaklı kategorileri ikiye ayrılmış durumdadır. Bu iki kategori birikimli olarak yine en büyük kitleyi ortaya koymaktadır. Bu bakımdan her iki çalışmanın bulgularının tutarlı olduğu söylenebilir.

\section{Öneriler}

1. Bu araştırmada, KAÇD çalışmalarının çoğunlukla üniversite öğrencileriyle veya KAÇD eğitimcileriyle gerçekleştirildiği sonucuna ulaşılmıştır. Bu anlamda K-12 seviyesinde KAÇD’lerle ilgili olarak yeterli bilgi birikimi yoktur. Buradan hareketle gelecek araştırmalarda K-12 seviyesinde (en azından lise kesiminde) yeni KAÇD araştırmaları yürütülebilir. Yapı gereği yetişkin eğitimine daha uygun olan KAÇD’lerin, yine de, K-12 seviyesinde uygulanıp uygulanamayacağına ilişkin daha çok görgül araştırmaya gereksinim duyulmaktadır. Bu çalışmaların öğretmenler veya öğrenciler penceresinden yürütülmesinin önemli saptamalar üretebileceği ileri sürülebilir.

2. Bu araştırmada, Pilli ve Admiraal (2016) tarafından ortaya konan açıklık ve kitlesellik durumlarına göre KAÇD sınıflamasının ilk çeyreğine karşılık gelen KAÇD’lerle araştırmalar yapıldığı görülmektedir. Bu çeyrek küçük ölçekli ve daha az açık olan KAÇD’ler ile ilgilidir ve 200-500 öğrenen ile sınırlıdır. Buradan hareketle, daha büyük ölçekli KAÇD’lerle araştırmalar yapılabilir. Özellikle Dünya geneline yayılmış, pek çok ülke ve hatta kıtadan katılımcısı olan KAÇD’lerde yapılacak tarama çalışmalarının daha kapsayıcı ve kültürlerarası kıyaslamaya olanak sağlayan sonuçlar ortaya koyacağı açıktır.

3. $\mathrm{Bu}$ araştırmada KAÇD araştırmalarında genellikle kuramsal temellerin vurgulanmadığı bulgusuna ulaşılmış, bu bulgu alan yazınla da desteklenmiştir. Buradan hareketle araştırmacıların çalışmalarında hangi kuramsal temeli dikkate aldıklarını 
vurgulamaları, sonuçların doğurgularının daha iyi okunabilmesine olanak tanıyacaktır. Araştırmacıların çalışmalarına hangi bakış açısından yaklaştıklarının bilinmesi, okurlar için de daha anlamlı ve aydınlatıcı olacaktır.

4. Araştırmalarda genellikle tarama türünden görgül çalışmaların yapıldığı sonucuna ulaşılmıştır. Bu bulguya paralel olarak betimsel istatistiklerin kullanılması da şaşırtıcı bir sonuç olarak görülmemektedir. Buradan hareketle, KAÇD araştırmalarına yönelik daha çok kestirimsel çalışmaya ihtiyaç vardır. Büyük kitlelerle deneysel çalışma yapılması elbette mümkün görülmemektedir ama populasyondan örneklem çekilerek, yine de deneysel çalışmalar tasarlanabilir. İyi kurgulanan ve desenlenen deneysel çalışmaların, tarama türündeki çalışmalara göre daha güçlü istatistiklerle, daha kesin sonuçlar söyleyebileceği düşünülmektedir.

5. KAÇD çalışmalarının 5'de 1'inin tasarım nitelikli çalışmalar olduğu görülmüştür. Burada tasarımdan kastedilenin KAÇD’lerin tasarlanması süreci olduğu bilinmektedir. Ancak bu tasarım sürecinde öğretim tasarımı ilkelerinin izlenip izlenmediğine ilişkin daha çok araştırmaya ihtiyaç vardır.

6. Son olarak bu araştırmanın tarama sürecine dâhil edilen KAÇD çalışmaların çoğunluğunun henüz hiç atıf almamasından hareketle, alan yazında daha nitelikli araştırmalara gereksinim duyulduğu söylenebilir.

\section{Sinirlılıklar}

$\mathrm{Bu}$ araştırmada elde edilen bulgular, Web of Science veritabanında yer alan ve Social Sciences Citation Index (SSCI), Arts and Humanities Citation Index (AHCI), Science Citation Index - Expanded (SCI-E) ve Emerging Sources Citation Index (ESCI) indekslerinde taranan makalelerin tematik içerik analizi ile elde edilmiştir. Elde edilen bulgu ve sonuçlar, ancak aynı bağlam içerisinde değerlendirildiğinde genellenebilir. Dolayısıyla daha geniş ve kapsamlı veritabanları taranarak farklı araştırma bulgularına ulaşılabilir. Ayrıca bu araştırma, yalnızca İngilizce yazılan ve hakemli dergilerde yayımlanan, tam metin erişimli makaleler ile sınırlıdır. Farklı dillerde yapılan KAÇD çalışmalarını ve makale türü dışındaki diğer araştırmaları (kitap bölümü, bildiriler, kitap inceleme yazıları ve düşünce yazıları gibi) kapsamamaktadır. 
Bilgilendirme

Bu çalışma, birinci yazarın ikinci yazar danışmanlığında tamamlamış olduğu yüksek lisans tezinden üretilmiştir.

Bu çalışmada kullanılan verilerin 2020 yılı öncesine ait olduğu araştırmacılar tarafından onaylanmıştır.

Yazar Katkı Beyanı

Burcu HAYMANA: Kavramsallaştırma, yöntem, doküman incelemesi, bulguların çıkarılması, yorumlar ve tartışma

Gökhan DAĞHAN: Kuramsal çerçeve, yazım, kontrol ve düzenleme

\section{Kaynaklar}

Baggaley, J. (2013). MOOC rampant. Distance Education, 34(3), 368-378.

Baggaley, J. (2014). MOOC postscript. Distance Education, 35(1), 126-132.

Bozkurt, A., Akgün-Özbek, E., \& Zawacki-Richter, O. (2017). Trends and patterns in massive open online courses: review and content analysis of research on MOOCs (2008-2015). International Review of Research in Open and Distributed Learning, 18(5), 118-146. doi: 10.19173/irrodl.v18i5.3080

Bozkurt, A., Özdamar Keskin, N., \& de Waard, I. (2016). Research trends in massive open online course (MOOC) theses and dissertations: Surfing the tsunami wave. Open Praxis, 8(3), 203-221. doi: 10.5944/openpraxis.8.3.287

Chen, Y.-H., \& Chen, P.-J. (2015). MOOC study group: Facilitation strategies, influential factors, and student perceived gains. Computers $\mathcal{E}$ Education, 86, 55-70.

Colvin, K. F., Champaign, J., Liu, A., Zhou, Q., Fredericks, C., \& Pritchard, D. E. (2014). Learning in an introductory physics MOOC: All cohorts learn equally, including an oncampus class. International Review of Research in Open and Distance Learning, 15(4), 263282. doi: 10.19173/irrodl.v15i4.1902

Çalık, M., \& Sözbilir, M. (2014). İçerik analizinin parametreleri. Eğitim ve Bilim, 39(174), 33-38. doi: 10.15390/EB.2014.3412

de Barba, P. G., Kennedy, G. E., \& Ainley, M. D. (2016). The role of students' motivation and participation in predicting performance in a MOOC. Journal of Computer Assisted Learning, 32(3), 218-231. doi: 10.1111/jcal.12130

Demiraslan-Çevik, Y. (2015). Yeni (?) bir öğrenme kuramı olarak bağlantıcılık. B. Akkoyunlu, A. İşman ve H. F. Odabaşı (Ed.) içinde Eğitim teknolojileri okumalar 2015, (9. Bölüm, ss. 177-194). TOJET-The Turkish Online Journal of Educational Technology.

Dillahunt, T., Wang, Z., \& Teasley, S. D. (2014). Democratizing higher education: Exploring MOOC use among those who cannot afford a formal education. The International Review of Research in Open and Distributed Learning (IRRODL), 15(5), 177-196.

Dunaway, M. K. (2011). Connectivism: Learning theory and pedagogical practice for networked information landscapes. Reference Services Review, 39(4), 675-685.

Ebben, M., \& Murphy, J. S. (2014). Unpacking MOOC scholarly discourse: A review of nascent MOOC scholarship. Learning, Media and Technology, 39(3), 328-345. 
Edwards, R. (1995). Different discourses, discourses of difference: Globalisation, distance education, and open learning. Distance Education, 16(2), 241-255.

Gašević, D., Kovanović, V., Joksimović, S., \& Siemens, G. (2014). Where is research on massive open online courses headed? A data analysis of the MOOC research initiative. The International Review of Research in Open and Distributed Learning, 15(5), 134-176.

Hone, K. S., \& El Said, G. R. (2016). Exploring the factors affecting MOOC retention: A survey study. Computers \& Education, 98(July 2016), 157-168.

Hood, N., Littlejohn, A., \& Milligan, C. (2015). Context counts: How learners' contexts influence learning in a MOOC. Computers $\mathcal{E}$ Education, 91, 83-91.

İkinci, A. S. (2016). The salient components of Massive Open Online Courses (MOOCs) as revealed in scholarly publications. Yayımlanmamış Yüksek Lisans Tezi, İhsan Doğramacı Bilkent Üniversitesi, Eğitim Bilimleri Enstitüsü, Ankara.

Knox, J. (2014). Digital culture clash: "massive" education in the E-learning and Digital Cultures MOOC. Distance Education, 35(2), 164-177. doi: 10.1080/01587919.2014.917704

Li, N., Verma, H., Skevi, A., Zufferey, G., Blom, J., \& Dillenbourg, P. (2014). Watching MOOCs together: investigating co-located MOOC study groups. Distance Education, 35(2), 217-233. doi: 10.1080/01587919.2014.917708

Lin, C.-H., \& Zhang, Y. (2014). MOOCs and Chinese language education. Journal of Technology and Chinese Language Teaching, 5(2), 49-65.

Liyanagunawardena, T. R., Adams, A. A., \& Williams, S. A. (2013). MOOCs: A systematic study of the published literature 2008-2012. International Review of Research in Open and Distributed Learning, 14(3), 202-227. doi: 10.19173/irrodl.v14i3.1455

Liyanagunawardena, T. R., Lundqvist, K. Ø., \& Williams, S. A. (2015). Who are with us: MOOC learners on a FutureLearn course. British Journal of Educational Technology, 46(3), 557-569.

Mackness, J., Waite, M., Roberts, G., \& Lovegrove, E. (2013). Learning in a small, taskoriented, connectivist MOOC: Pedagogical issues and implications for higher education. The International Review of Research in Open and Distributed Learning, 14(4), 140-159.

Naidu, S. (2019). The idea of open education. Distance Education, 40(1), 1-4.

Pilli, O., \& Admiraal, W. (2016). A taxonomy of massive open online courses. Contemporary Educational Technology, 7(3), 223-240.

Raffaghelli, J. E., Cucchiara, S., \& Persico, D. (2015). Methodological approaches in MOOC research: Retracing the myth of Proteus. British Journal of Educational Technology, 46(3), 488-509.

Rodriguez, C. O. (2012). MOOCs and the AI-Stanford like courses: Two successful and distinct course formats for massive open online courses. European Journal of Open, Distance and E-Learning, 3. http://www.eric.ed.gov/PDFS/EJ982976.pdf adresinden 15.01.2018 tarihinde erişilmiştir.

Sa'don, N. F., Alias, R. A., \& Ohshima, N. (2014). Nascent research trends in MOOCs in higher educational institutions: A systematic literature review. 2014 International Conference on Web and Open Access to Learning (ICWOAL), 25-27 November, Dubai, United Arab Emirates.

Salmon, G., Gregory, J., Dona, K. L., \& Ross, B. (2015). Experiential online development for educators: The example of the Carpe Diem MOOC. British Journal of Educational Technology, 46(3), 542-556. doi:10.1111/bjet.12256

Sanchez-Gordon, S., \& Luján-Mora, S. (2014, March). MOOCs gone wild. Paper presented at the $8^{\text {th }}$ International Technology, Education and Development Conference. Valencia, Spain. 
Sayın, Z., \& Seferoğlu, S. S. (2015). Çevrim-içi öğrenmeye yeni bir bakış açısı: Kitlesel açık çevrimiçi dersler. B. Akkoyunlu, A. İşman ve H. F. Odabaşı (Ed.) içinde Ĕ̆̆itim teknolojileri okumaları 2015, (26. Bölüm, ss. 525-538). TOJET-The Turkish Online Journal of Educational Technology.

Schreirer, M. (2012). Qualitative content analysis in practice. Thousand Oaks, California: Sage Publ.

Siemens, G. (2005a). Connectivism: Learning as Network-Creation. 28.04.2016 tarihinde http://www.elearnspace.org/Articles/networks.htm adresinden erişilmiştir.

Siemens, G. (2005b). Connectivism: A learning theory for a digital age. International Journal of Instructional Technology and Distance Learning, 2(1).

Siemens, G., \& Downes, S. (2008). Connectivism \& Connective Knowledge. http://connect.downes.ca/archive/08/09_08_thedaily.htm adresinden 01.02.2019 tarihinde erişilmiştir.

Siemens, G. \& Tittenberger, P. (2009). Handbook of emerging technologies for learning. http://www.aps.edu/educational-technology/documents/handbook-of-emergingtechnologies-for-learning/at_download/file adresinden 23.03.2019 tarihinde erişilmiştir.

Veletsianos, G., \& Shepherdson, P. (2016). A systematic analysis and synthesis of the empirical MOOC literature published in 2013-2015. International Review of Research in Open and Distributed Learning, 17(2), 198-221. doi: 10.19173/irrodl.v17i2.2448

Watson, S. L., Loizzo, J., Watson, W. R., Mueller, C., Lim, J., \& Ertmer, P. A. (2016). Instructional design, facilitation, and perceived learning outcomes: An exploratory case study of a human trafficking MOOC for attitudinal change. Educational Technology Research and Development, 64(6), 1273-1300. doi: 10.1007/s11423-016-9457-2

Watson, W. R., Kim, W., \& Watson S. L. (2016). Learning outcomes of a MOOC designed for attitudinal change: A case study of an animal behavior and welfare MOOC. Computers E Education, 96, 83-93. doi: 10.1016/j.compedu.2016.01.013

Yousef, A. M. F., Chatti, M. A., Wosnitza, M., \& Schroeder, U. (2015). A cluster analysis of MOOC stakeholder perspectives. RUSC. Universities and Knowledge Society Journal, 12(1), 74-90. doi: 10.7238/rusc.v12i1.2253

Zhu, M., Sari, A., \& Lee, M. M. (2018). A systematic review of research methods and topics of the empirical MOOC literature (2014-2016). The Internet and Higher Education, 37, 31-39. 